\title{
Rapid climatic variability in the west Mediterranean during the last 25000 years from high resolution pollen data
}

\author{
N. Combourieu Nebout ${ }^{1}$, O. Peyron ${ }^{2}$, I. Dormoy ${ }^{2}$, S. Desprat ${ }^{1}$, C. Beaudouin ${ }^{2}$, U. Kotthoff $^{3}$, and F. Marret ${ }^{4}$ \\ ${ }^{1}$ Laboratoire des Sciences du Climat et de l'Environnement, UMR 1572 CNRS/CEA/UVSQ, \\ 91198 Gif sur Yvette Cedex, France \\ ${ }^{2}$ Laboratoire de Chrono-Environnement, UMR 6249 CNRS, Université de Franche-Comté, UFR des Sciences et Techniques, \\ 16 route de Gray, 25030 Besançon, France \\ ${ }^{3}$ Department of Geosciences, Hamburg University, Bundesstrasse 55, 20146 Hamburg, Germany \\ ${ }^{4}$ Department of Geography, Roxby Building, University of Liverpool, Liverpool, L69 7ZT, UK
}

Received: 20 January 2009 - Published in Clim. Past Discuss.: 24 February 2009

Revised: 30 July 2009 - Accepted: 4 August 2009 - Published: 11 September 2009

\begin{abstract}
High-temporal resolution pollen record from the Alboran Sea ODP Site 976, pollen-based quantitative climate reconstruction and biomisation show that changes of Mediterranean vegetation have been clearly modulated by short and long term variability during the last 25000 years. The reliability of the quantitative climate reconstruction from marine pollen spectra has been tested using $22 \mathrm{ma}-$ rine core-top samples from the Mediterranean. The ODP Site 976 pollen record and climatic reconstruction confirm that Mediterranean environments have a rapid response to the climatic fluctuations during the last Termination. The western Mediterranean vegetation response appears nearly synchronous with North Atlantic variability during the last deglaciation as well as during the Holocene. High-resolution analyses of the ODP Site 976 pollen record show a cooling trend during the Bölling/Allerød period. In addition, this period is marked by two warm episodes bracketing a cooling event that represent the Bölling-Older Dryas-Allerød succession. During the Holocene, recurrent declines of the forest cover over the Alboran Sea borderlands indicate climate events that correlate well with several events of increased Mediterranean dryness observed on the continent and with Mediterranean Sea cooling episodes detected by alkenonebased sea surface temperature reconstructions. These events clearly reflect the response of the Mediterranean vegetation to the North Atlantic Holocene cold events.
\end{abstract}

Correspondence to:

N. Combourieu Nebout

(nathalie.nebout@1sce.ipsl.fr)

\section{Introduction}

In the context of future global warming, the Mediterranean world region will clearly be one of the most sensitive region to climate changes due to its intermediate geographical position at the junction of the tropical and polar influences (Lionello et al., 2006; IPCC report, 2007). The predicted climate changes might have a large influence on its particular environments and dense population as well as mitigation and adaptation scenarios (IPCC report, 2007). Understanding the present and future environmental changes in the Mediterranean includes discriminating natural global variability from human impact. Studying past environmental changes yields a large amount of information in order to draw the complex picture of climate changes. Numerous records have demonstrated that Mediterranean environments show rapid responses to climatic fluctuations during the last climatic cycle (e.g. Allen et al., 2002; Beaudouin et al., 2007; Bout-Roumazeilles et al., 2007; Brauer et al., 2007; Cacho et al., 1999, 2001; Combourieu Nebout et al., 1999, 2002; Fletcher and Sánchez Goñi, 2008; Sánchez Goñi et al., 2002; Watts et al., 1996; Kotthoff et al., 2008a). This is probably due to the climate specificity of the Mediterranean region that combines polar tropical and Atlantic influences generating very sensitive environments strongly adapted to the hot dry summer and mild humid winter. A number of multiproxy records have demonstrated that Mediterranean environments have responded to short-term Holocene climatic events (e.g. Cacho et al., 2001; Frigola et al., 2007; Rohling et al., 1998, 2002). Few pollen-based studies provide evidence of a clear response of the Mediterranean vegetation to

Published by Copernicus Publications on behalf of the European Geosciences Union. 
these short-lived Holocene events (Allen et al., 2002; Jalut et al., 2000; Naughton et al., 2007). Several qualitative climate interpretations, mainly based on lacustrine records, have already been obtained for part of this period; however, they differ significantly, particularly regarding the Mediterranean area (e.g. Sadori and Narcisi, 2001; Antonioli et al., 2001; Marchal et al., 2002; Magny et al., 2007). This is mainly due to the scarcity of high-resolution sequences covering the last 25000 years in this region. There is also a lack of robust quantitative estimates of climate parameters in Southern Europe and the Mediterranean for the last 25000 years (Huntley and Prentice, 1988; Huntley et al., 1999; Allen et al., 2002; Cheddadi et al., 1997, 1998; Davis et al., 2003; Brewer et al., 2007; Fletcher et al., 2009; Dormoy et al., 2009).

In order to investigate the sensitivity of Mediterranean vegetation to the last deglaciation and Holocene events, we present here high temporal resolution pollen analyses of the last 25000 years from ODP Leg 161 Site 976 (Alboran Sea). This detailed study allows us to identify centennial to millennial scale vegetation changes in the western Mediterranean and to reconstruct quantitative estimations of climatic parameters.

This study aims to provide a new high resolution pollen record and a reliable picture of paleoclimatic variations in the Mediterranean region for the last 25000 years BP in order to improve the state-of-the-art on environmental changes of the last deglaciation and Holocene (e.g. Allen et al., 2002; Cacho et al., 2001; Frigola et al., 2007; Naughton et al., 2007; Jalut et al., 2000; Björk et al.; 1998; Bond et al., 1997; Lowe et al.; 2008; Magny et al., 2006, 2007; Drescher-Schneider et al., 2007; Colombaroli et al.; 2008; Rasmussen et al., 2007, 2008; Jalut et al., 2009).

\section{Location and environmental setting}

ODP Leg 161 Site 976 was drilled in the Alboran Sea $\left(36^{\circ} 12 \mathrm{~N}, 4^{\circ} 18 \mathrm{~W}\right)$ close (at about $\left.110 \mathrm{~km}\right)$ to the Gibraltar strait by the Joides resolution at $1108 \mathrm{~m}$ water depth (Fig. 1) (Comas et al., 1996). The Alboran Sea is bordered by the two Arc Mountains of Betic cordillera in Spain and Rif in Morocco. Climate is dominated by the influence of the Southern Azores anticyclone in summer and the midlatitude atmospheric circulation in winter that results in a Mediterranean climate with long, dry summers (3 to more than 5 months) and mild, rainy winters (Walter et al., 1975; Quézel and Médail, 2003). The Westerlies, that dominate the wind regime during winter, are weaker during summer due to the influence of the Azores anticyclone. The river system in the surrounding continents does not display important rivers and, then large riverine inputs to the Alboran Sea mainly come from Mediterranean local torrential rains. Aridity reaches a maximum along the southern Spanish coast, but peaks of precipitation occur in the Spanish hinterlands during spring and autumn. In Northern Africa, rainfall is con-

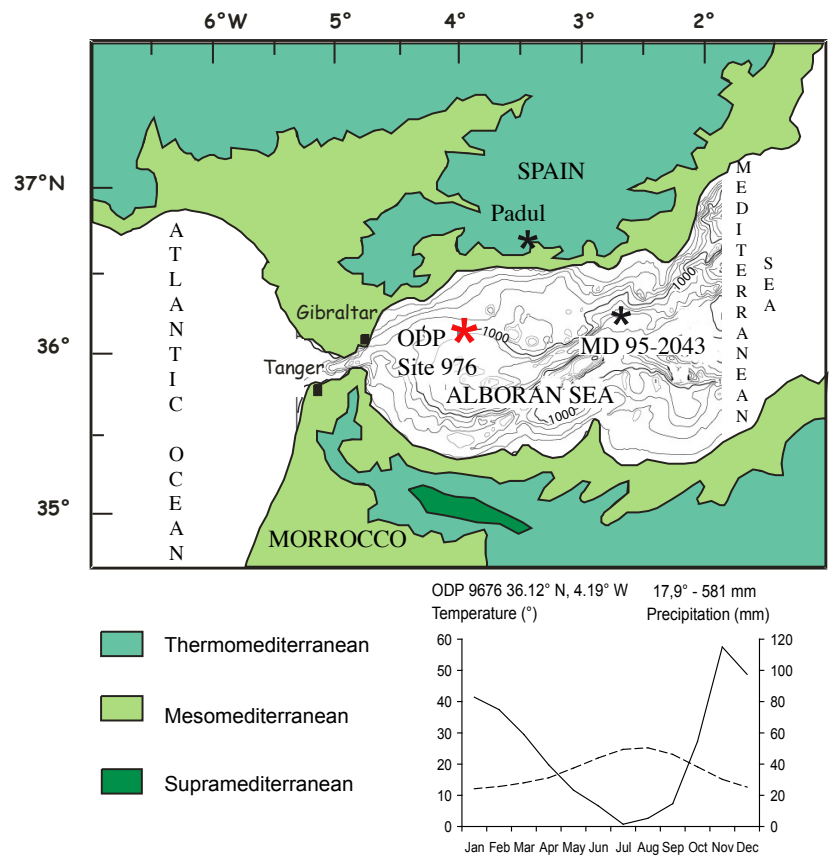

Fig. 1. Location map of the ODP Leg 161 Site 976. Climate diagram showing the present-day climate (annual precipitation and temperature distribution) at the studied site calculated with the New Locclim software.

centrated near the coast from autumn to spring and sharply decreases southward (Walter et al., 1975) (Fig. 1). In both areas, the Atlantic influence is marked by increasing humidity in the western lands. The presence of the two Arc Mountains (Moroccan Rif and Betic Cordillera) implies increasing humidity and decreasing temperature, and climate conditions range from semi-arid near the coast to wet at high elevations. Thus mean temperature of the coldest month varies from less than $10^{\circ} \mathrm{C}$ near the coast to values between $-7^{\circ}$ and $0^{\circ} \mathrm{C}$ at high altitude (above $2000 \mathrm{~m}$ ) while mean temperature of the warmest month is generally greater than $20^{\circ} \mathrm{C}$ and mean annual temperature around $18^{\circ} \mathrm{C}$. Annual precipitation ranges from less than $400 \mathrm{~mm}$ in the lowlands to more than $1400 \mathrm{~mm}$ in the Betic and Rif mountains (Quézel and Médail, 2003; Grieser et al., 2006). Such climatic and geographic conditions in the Moroccan Rif and in the Betic Cordillera generate thermal and hydrologic gradients with altitudinal elevation. As a consequence, the climate ombrothermic diagram calculated for the Alboran Sea by New LocClim software does not well represent these gradients (Fig. 1) (Grieser et al., 2006). As a result, Mediterranean landscapes are here organised in altitudinal belts according to the ecologic and climatic requirements of the plants (Ozenda, 1975; Rivas Martinez, 1982; Polunin and Walter, 1985; Barbero et al., 1981; Benabib, 1982, 2000; Quézel, 2002; Quézel and Médail, 2003). Modern vegetation environments are divided into four classifications. A thermomediterranean belt is found 
in the lowlands with Olea/Pistacia sclerophillous shrublands and some associated steppe or semi-desert representatives (Artemisia, Chenopodiaceae, Ephedra). At mid-altitudes the mesomediterranean belt is represented by the sclerophyllous oak forest and the humid-temperate oak forest (eurosiberian trees, mainly deciduous Quercus and Ericaceae). The higher altitudes are characterised by a supramediterranean belt with a cold-temperate coniferous forest (Pinus, Abies and/or $\mathrm{Ce}$ $d r u s$, the latter growing only in Morocco today at high elevation).

\section{Methodology}

\subsection{Chronology}

This study is based on the uppermost $10 \mathrm{~m}$ of the ODP Site 976 core. The sediments consist of homogeneous clays (Comas et al., 1996). The age model developed for the studied interval is based on ten ${ }^{14} \mathrm{C}$ AMS radiocarbon ages performed on monospecific samples of Globigerina bulloïdes and Neogloboquadrina pachyderma (left coiling) from the size fraction $>125 \mu \mathrm{m}$, at the Leibniz-Laboratory of Kiel University (Combourieu Nebout et al., 2002) (Fig. 2). ${ }^{14} \mathrm{C}$ ages have been corrected by 400 years to account for ${ }^{14} \mathrm{C}$ reservoir age of the modern Alboran Sea surface water. We are however aware that some modifications of ${ }^{14} \mathrm{C}$ reservoir ages may have occurred during the studied interval (Bard, 1998; Siani et al., 2000, 2001). Conversions into calendar years have been done using the calibrations of Bard et al. (1998), Stuiver and Reimer (1993) and Stuiver et al. (1998).

According to our age model, presented here in an age/depth diagram (Fig. 2), our record spans the last 25000 calendar (cal.) years (Figs. 5 to 8). Sedimentation rate appears quite constant along the whole sequence although the ${ }^{14} \mathrm{C}$ dates are unevenly spread in depth. Thus the time resolution between samples varies from $\sim 20-40$ years during the abrupt events to $200-500$ years elsewhere.

\subsection{Pollen data}

This core was sampled at $10 \mathrm{~cm}$ intervals and every 1$5 \mathrm{~cm}$ during the Bölling/Allerød and the beginning of the Holocene. Pollen extractions followed the classic protocol (Faegri and Iversen, 1964; Combourieu Nebout et al., 2002): after drying, samples were processed with $25 \%$ cold $\mathrm{HCl}$, cold $70 \% \mathrm{HF}, 50 \% \mathrm{HCl}$ and sieved on a $10 \mu \mathrm{m}$ sift. Due to the over-representation of Pinus pollen grains in marine sediments (Heusser and Balsam, 1977; Turon, 1984), each pollen count always comprises from 300 to 1600 pollen grains, including at least 100 and more often 300 pollen grains without Pinus. Moreover, each pollen analysis generally includes the determination of at least twenty taxa. Pinus pollen percentages were calculated on the total pollen sum as well as

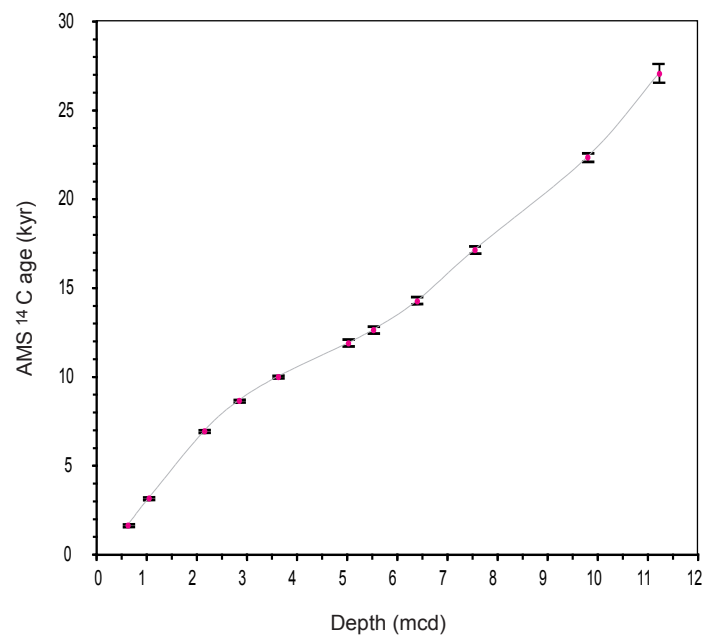

Fig. 2. ODP Leg 161 Site 976 age-depth model. ${ }^{14} \mathrm{C}$ ages have been corrected by the $400 \mathrm{yr}$ reservoir age. Depths are in meter composite depth (mcd).

the pollen curves of the synthetic pollen diagram. Individual pollen percentages were calculated on a sum excluding Pinus to highlight the variations of the other taxa which are often dampened due to Pinus over-representation in marine sediments. Pollen analysis yielded a rich microflora with 120 pollen taxa identified.

Pollen grain transport in the marine realm has been largely debated and it has been admitted for a long time that pollen grains carried by wind and /or rivers to marine sediments come from the nearby continental areas (e.g. Heusser and Balsam, 1977; Hooghiemstra et al., 1992, 1995, 2006; Turon, 1984; Naughton et al., 2007). Thus, palynological interpretations for the ODP Site 976 sequence are based on the assumption that pollen grains mainly come from the borderlands of the Alboran Sea basin, essentially Morocco and Spain. The fossil pollen spectrum ranges from semi-desert vegetation to mountain deciduous and coniferous forest allowing that the interpretation follows the modern climaticplant relationships in Eurasia and Northern Africa (Woodwards, 1987; Peyron et al., 1998).

\subsection{Pollen-inferred climate reconstructions and biomisation}

The Modern Analogues Technique (MAT), also called the best analogues method, which was first developed by Hutson (1980) and Overpeck et al. (1985) and extended by Guiot (1990) to reconstruct climate parameters from fossil assemblages for past key periods, has been applied to the ODP 976 pollen sequence. This method has been extensively used for the Late glacial and Holocene climate reconstructions in Europe (e.g. Cheddadi et al., 1997, 1998; Davis et al., 2003; Peyron et al., 2005; Bordon et al., 2009; Magny et al., 2009; Kotthoff et al., 2008). The principle of this technique is (1) 


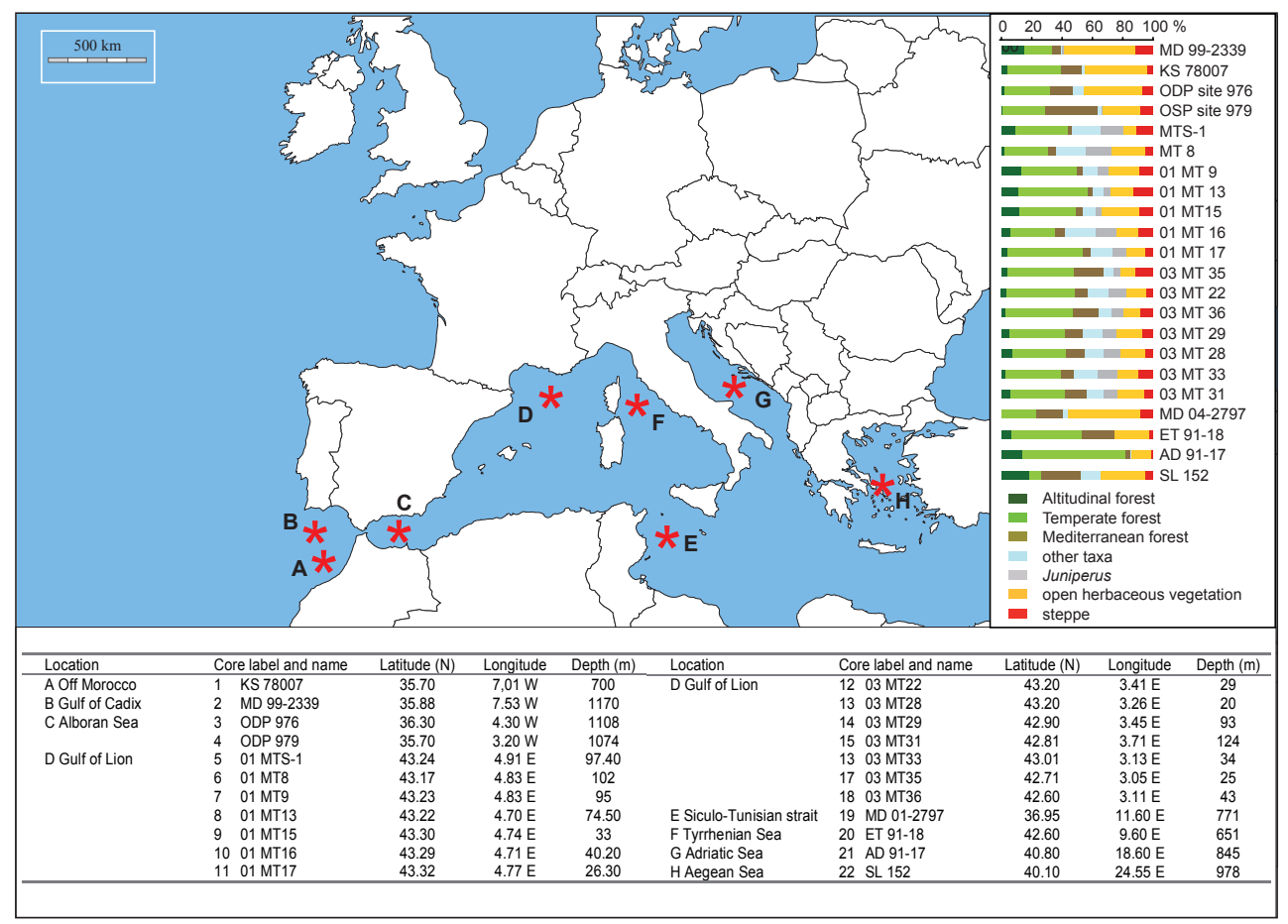

Fig. 3. Location map of the marine core-tops used for the comparison observed/reconstructed climate values. On the right: pollen spectra of the studied core-tops; at the bottom: names, coordinates and depth of the studied cores grouped according to the different basins.

to compare, using a dissimilarity index, the fossil pollen assemblages with the modern pollen assemblages collected in a high-quality and taxonomically consistent modern pollen dataset, (2) and to select, for each fossil assemblage, several closest modern pollen assemblages (or best modern analogues). The selection of the best modern analogues (here 10 ) is based on the calculation of a chord distance measured between each fossil and modern pollen assemblage (Guiot, 1990). The climatic values of each fossil assemblage are obtained as a weighted average of the climate parameters of the best analogues selected (Guiot, 1990). The climate parameters of each modern pollen record have been calculated and interpolated at each site using the high resolution database of climatic means of New et al. (2000). We have selected the mean temperature of the warmest month (Tsum) and coldest month (Twin), as these are important climate parameters controlling the plant distribution after Prentice et al. (1992), and also the mean annual temperature (Tann), mean monthly precipitation in summer (Psum) and mean monthly precipitation in winter (Pwin). We present the climate estimations in terms of anomalies to facilitate the comparison with other European climate reconstructions (Davis et al., 2003; Wu et al., 2007; Brewer et al., 2007) and model simulations (Kageyama et al., 2005; Wiesrma and Renssen, 2006).

The MAT, like most of the approaches which aim to quantitatively reconstruct the past climate from fossil assemblages, is based on present-day environments, and therefore requires high-quality, taxonomically consistent modern datasets. In this study, the method is based on an updated modern pollen-climate dataset which comprises 3530 pollen data sampled from a wide variety of biomes (Bordon et al., 2009). Among these 3530 samples, more than 2000 pollen spectra taken from mosses, soil or core samples are located in the Mediterranean basin (Spain, Morocco, Italia and Turkey). As Pinus is always over-represented in marine sediments, we removed this taxon from the modern spectra as well as from the fossil spectra.

The character of past vegetation and climate can be inferred from pollen analytical data in various ways, qualitative (pollen analyses and biomes) and quantitative (quantifications of climate parameters). In the present study, we have chosen to couple both approaches in order to reconstruct past vegetation changes by looking at the vegetation structure or biome. In Europe, 11 biomes are usually found in modern samples: tundra, cold deciduous forest, taiga, cool conifer forest, cold mixed forest, temperate deciduous forest, cool mixed forest, and more frequently in the Mediterranean area: warm mixed forest, xerophytic wood/shrub, steppes/temperate grassland, or desert. This approach allows the objective assignment of pollen taxa to plant functional types (PFTs) and to biomes on the basis of the modern plant ecology, bioclimatic tolerance and phenology. We applied the biomisation technique described by Prentice et al. (1996), adapted by Peyron et al. (1998), Tarasov et al. (1999a and b) and largely used in Europe (Müller et al., 2009) and the Mediterranean (e.g. Allen et al., 2002; Huntley et al., 2003; 

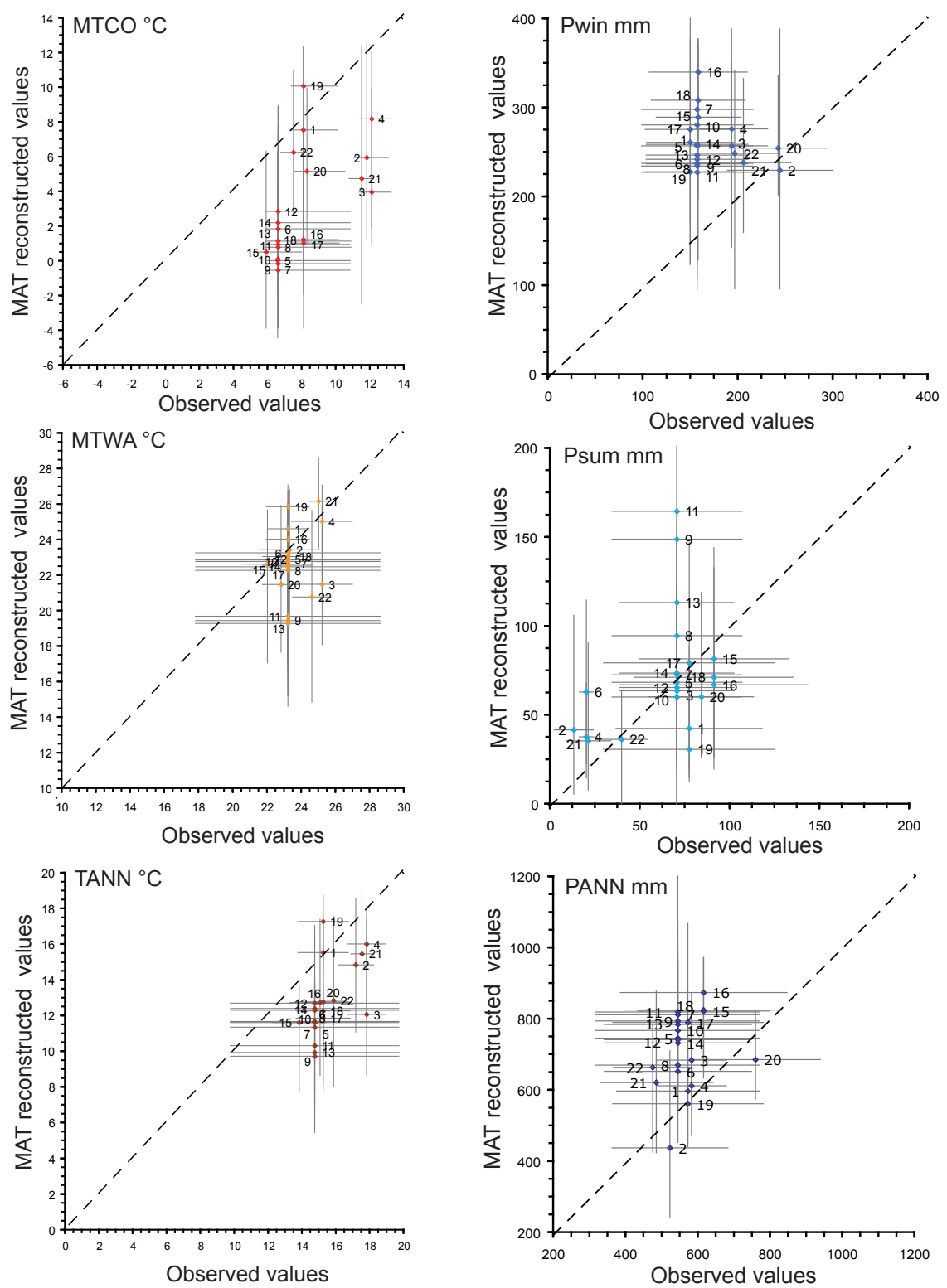

Fig. 4. Comparison between LocClim observed and MAT reconstructed climate values from the core-tops. (a): temperature; (b): precipitation.

Bordon et al., 2009), to each marine pollen assemblage. For each sample, the associated biome has been defined following the plant functional type-biome assignment procedure based on Prentice et al. (1996) and Peyron et al. (1998).

In order to further test the reliability of the MAT on marine pollen samples, we have applied this method to 22 coretop samples reflecting modern climate conditions in the Atlantic and Circum-Mediterranean regions. The core-top sediments were collected from the Morocco shelf, Gulf of Cadix, Alboran Sea, Gulf of Lion, Tyrrhenian Sea, Adriatic Sea, Aegean Sea and Siculo-Tunisian strait (Figs. 3 and 4). Pollen counts of the core-top samples reflect a good representation of the vegetation of each studied area, as in other stud- ies based on marine superficial sediments off Europe and off West Africa (e.g. Naughton et al., 2007; Hooghiemstra et al., 1995). However, Mediterranean taxa appear underrepresented in most of the marine spectra. The MAT reconstructions are based on the modern pollen dataset from Bordon et al. (2009) described previously. The comparison between the present day observed (Locclim software, Gieser et al., 2006) and MAT reconstructed values of several climatic parameters (Tann, Tsum, Twin, Pann, Pwin and Psum) shows an adequate consistency considering the estimation errors, especially for Tsum, Psum and Pann (Fig. 4a and $b$, Table 1). Paired samples t-tests show that there is no significant difference in the means of the observed and 
Table 1a. Relationship between observed and reconstructed climatic parameters (core-tops grouped according to the different basins): mean discrepancies calculated for the temperature (a) and precipitation (b); paired samples T-test for means (c).

\begin{tabular}{llrrrrrrrrr}
\hline Mean difference & Core numbers & Twin & Twin - & Twin + & Tsum & Tsum - & Tsum + & Tann & Tann - & Tann + \\
\hline Off Morocco & 1 & -0.53 & -5.15 & 2.32 & 1.43 & -1.76 & 2.45 & 0.31 & -4.05 & 2.06 \\
Gulf of Cadix & 2 & -5.83 & -9.27 & -0.48 & 0.15 & -2.23 & 1.75 & -2.30 & -5.00 & 0.41 \\
Alboran Sea & 3.4 & -6.01 & -9.54 & -2.19 & -1.92 & -3.91 & -0.46 & -3.74 & -6.40 & -1.17 \\
Gulf of Lion & 5 to 18 & -5.91 & -5.88 & -4.42 & -0.95 & -1.74 & -2.44 & -3.17 & -2.82 & -3.91 \\
Siculo-Tunisian strait & 19 & 2.00 & -0.49 & 2.31 & 2.68 & 1.50 & 2.63 & 2.06 & 0.71 & 1.99 \\
Tyrrhenian Sea & 20 & -3.12 & -4.99 & -0.53 & -1.31 & -4.04 & 2.07 & -2.31 & -4.61 & 0.59 \\
Adriatic Sea & 21 & -6.74 & -13.28 & 0.19 & 1.19 & -0.83 & 3.02 & -2.05 & -5.07 & 0.61 \\
Aegean Sea & 22 & -1.22 & -4.04 & 2.78 & -3.82 & -8.62 & -0.06 & -2.97 & -7.07 & 0.99 \\
\hline Mediterranean area & & -3.4 & -6.6 & 0 & -0.3 & -2.7 & 1.1 & -1.8 & -4.2 & 0.2 \\
\hline
\end{tabular}

Table 1b. Continued.

\begin{tabular}{llrrrrrrrrr}
\hline Mean difference & Core numbers & Pwin & Pwin - & Pwin + & Psum & Psum - & Psum + & Pann & Pann - & Pann + \\
\hline Off Morocco & 1 & 111.54 & 22.37 & 205.38 & -34.65 & -21.53 & -29.07 & 26.50 & 79.16 & -84.61 \\
Gulf of Cadix & 2 & -14.20 & -92.38 & 89.64 & 28.79 & 3.45 & 82.36 & -83.96 & -117.76 & 29.09 \\
Alboran Sea & 3.4 & 73.66 & -11.26 & 139.72 & 30.39 & 2.55 & 67.61 & 67.67 & 38.64 & 182.47 \\
Gulf of Lion & 5 to 18 & 110.23 & 48.78 & 153.80 & 12.21 & -8.99 & 40.39 & 213.38 & 229.91 & 207.12 \\
Siculo-Tunisian strait & 19 & 78.49 & 69.75 & 84.03 & -46.47 & -16.82 & -58.05 & -9.42 & 77.66 & -13.26 \\
Tyrrhenian Sea & 20 & 12.76 & 12.13 & 42.16 & -23.55 & -28.99 & 6.01 & -72.83 & -4.32 & -114.12 \\
Adriatic Sea & 21 & 33.08 & 4.76 & 77.01 & 14.50 & -0.56 & 57.15 & 137.82 & 96.08 & 239.56 \\
Aegean Sea & 22 & 52.50 & -54.93 & 100.69 & -3.21 & -25.00 & 9.85 & 190.47 & 60.45 & 201.37 \\
\hline Mediterranean area & & 57.3 & 0 & 111.6 & -2.8 & -12.0 & 22.0 & 58.7 & 57.48 & 81.0 \\
\hline
\end{tabular}

Table 1c. Continued.

\begin{tabular}{lrrrrrr}
\hline T-test: Paired samples for means & Twin & Tsum & Tann & Pwin & Psum & Pann \\
H0=0, alpha=0.05, DF=7, & & & & & & \\
$t$ (critical value)=2.366 & & & & & & \\
\hline Mean Difference & -3.419 & -0.319 & -1.770 & 57.257 & -2.750 & 58.705 \\
$t$ (Observed value) & -3.008 & -0.431 & -2.553 & 3.600 & -0.266 & 1.457 \\
$p$-value (Two-tailed) & 0.020 & 0.679 & 0.038 & 0.009 & 0.798 & 0.189 \\
\hline
\end{tabular}

reconstructed values of these three climatic parameters (Table 1c). Nevertheless the MAT regularly seems to underestimate the Twin values by about $\sim 3^{\circ} \mathrm{C}$ in comparison with the observed values and to overestimate the Pwin by about $\sim 60 \mathrm{~mm}$ (Table 1a and b). As a result, differences between observed and reconstructed values are also observed in Tann $\left(\sim 2^{\circ} \mathrm{C}\right)$ and Pann $(\sim 60 \mathrm{~mm})$ (Table $1 \mathrm{a}$ and $\left.\mathrm{b}\right)$. The discrepancies are probably linked, on the one hand, to a weak representation of Mediterranean taxa in most of the marine pollen spectra (Fig. 3) and to the lack of modern pollen analogues in Tunisia, Libya and Egypt. Therefore, Northern Europe pollen analogues are often attributed to the Mediterranean marine spectra analysed. This induces a decrease in Twin values and an increase in the Pwin values. On the other hand, some biases inherent to the LocClim software influence the observed estimations because calculations rely on a limited number of meteorological stations that are inhomogeneously distributed and particularly scarce at high elevations, and chosen inside a restricted perimeter. The software hardly provides an accurate integrated estimation of the climatic parameters at a regional scale like marine pollen data, in particular for mountainous areas. For example, for little basins such as the Alboran and Adriatic Seas, for which many meteorological stations are available at low altitudes, the software fails to integrate the altitude gradient in the climatic estimations. This causes an overestimation of observed temperature 
and an underestimation of precipitation, and consequently amplifies the discrepancy with the reconstructed values from marine pollen spectra that integrate the vegetation from different elevations.

\section{West Mediterranean vegetation and climate changes over the last 25000 yr BP}

Close relationship between continental vegetation and pollen grain content in marine surface sediments has already been clearly established in several studies that show the reliability of pollen analyses at regional-scale interpretations (Heusser and Balsam, 1977; Hoghiemstra et al., 1992, 1995, 2006; Turon, 1984; Naughton et al., 2007). The main part of pollen flora recorded in the ODP Site 976 record, such as the all inclusive components of the Quercus deciduous and Mediterranean forests, probably originates from Spain as well as from Morocco while the presence of Cedrus in noticeable percentages definitively marks inputs from the south (Quézel and Médail, 2003; Quézel, 2002; Magri et al., 2002). This indicates that, in the Alboran area, pollen spectra correspond to a combination of north and south supplies (BoutRoumazeilles et al., 2007), making our pollen record a reliable synthetic picture of the regional vegetation changes from the whole Alboran Sea area.

Moreover, the ODP pollen record is comparable with other marine pollen records from the Alboran Sea (Fletcher and Sánchez Goñi, 2008) and Portuguese margin (Turon et al., 2003; Naughton et al., 2007) as well as with terrestrial sequences from the Southern Spain (Pons and Reille, 1988; Carrión et al., 2007) and Northern Morocco (Cheddadi et al., 1998, 2009; Lamb et al., 1989). This similarity also shows the ability of the ODP Site 976 record to highlight the response of the Spanish and Moroccan vegetation to the successive climate events over the last 25000 years (Table 2, Fig. 2).

\subsection{Heinrich event 2 and late Pleniglacial}

Between 25000 and $23500 \mathrm{cal} \mathrm{yr} \mathrm{BP}$ (pollen zones 1 and 2, Fig. 5, Table 2), the pollen associations reflect a broad extension of steppe or semi-desert plants with the dominance of Artemisia and Chenopodiaceae, and a temperate forest reduction shown by very low percentages of deciduous Quercus (Table 2, Fig. 5). These vegetation assemblages are indicative of enhanced drought in the Alboran Sea borderlands that match the timing of the Heinrich 2 event (H2) (Elliot et al., 1998). Reconstructed biomes from pollen data correspond to an alternating of warm and cold steppe (Fig. 5). Pollen-inferred climatic parameters indicate that cold and dry conditions prevailed during $\mathrm{H} 2$ in the Alboran Sea region (anomaly values: $-20^{\circ} \mathrm{C}$ in winter; -15 to $-10^{\circ} \mathrm{C}$ in annual, $-8^{\circ} \mathrm{C}$ in summer; $-200 \mathrm{~mm}$ in winter, $+100 \mathrm{~mm}$ in summer) (Fig. 5). The annual temperature curve shows the same climate trend although with higher amplitude than the alkenone-based temperature record that indicates a decrease of about $3^{\circ} \mathrm{C}$ during $\mathrm{H} 2$ (Cacho et al., 1999, 2001) (Fig. 6). The semi-desert phase is contemporaneous with a peak of Neoglobiquadrina pachyderma left coiling and increasing abundance of the dinocyst Bitectatodinium tepikiense, both indicating a cooling in Alboran Sea surface temperatures (Combourieu Nebout et al., 2002). A similar synchronization between marine and continental changes during this time slice is also recorded in other Atlantic and Mediterranean cores (Combourieu Nebout et al., 1998, 2002; Sánchez Goñi et al., 2002; Turon et al., 2003; Naughton et al., 2007; Fletcher et al., 2008) and allows correlation of this episode with Heinrich event 2. In the ODP record, this event is placed between 25000 and $23500 \mathrm{cal} \mathrm{yr} \mathrm{BP}$, a time slice that corresponds well with the established ages for this event in the North Atantic (Bond et al., 1993; Elliot et al., 1998).

Between 23500 and $17500 \mathrm{cal} \mathrm{yr} \mathrm{BP}$, a time-period being assigned to the LGM (Mix et al., 2001; Kucera et al., 2005), the vegetation became a heathland, associated with cedar forest (probably at high altitude) after 20000 cal yr BP (Figs. 5 and 6). Such association contrasts with the Artemisia semi-desert association recognized during $\mathrm{H} 2$ and reflects a clear different climate, more humid but still cool. Reconstructed biomes are dominated by warm steppe with rare cold steppe/temperate grassland and temperate deciduous forest. The quantitative climate reconstruction indicates high amplitude climate oscillations during this period characterised by a slightly moist climate with cool temperatures in agreement with the pollen assemblages. Results show TANN anomalies around $-5^{\circ} \mathrm{C}$ with Twin $-10^{\circ}$ to $-15^{\circ} \mathrm{C}$ (Fig. 6). The anomalies are slightly lower during the Last Glacial Maximum that during the $\mathrm{H} 2$ event and are similar to the SST anomalies deduced from quantitative reconstructions of foraminifer associations (Hayes et al., 2005; Kuhleman et al., 2008). The LGM climate estimates from ODP Site 976 are consistent with those reconstructed for the Mediterranean region with the inverse vegetation modelling technique $(\mathrm{Wu}$ et al., 2007), and $5^{\circ} \mathrm{C}$ higher than the temperatures reconstructed with the plant functional type method (Peyron et al., 1998). These values are also in better agreement with the recent atmosphere general circulation model simulations for the Last Glacial Maximum period (Kageyama et al., 2005; Jost et al., 2005; Ramstein et al., 2007).

Between 21000 and $17500 \mathrm{cal} \mathrm{yr} \mathrm{BP,} \mathrm{it} \mathrm{is} \mathrm{noteworthy}$ that temperature and precipitation estimations are close to present-day conditions, that is clearly too warm and humid for LGM conditions. In addition, the biome assigned to the pollen association is "temperate deciduous forest" although the biome representatives such as Quercus are not the dominant taxa of the pollen spectra. This discrepancy is mirrored by the high distances recorded between ODP samples and the MAT analogues and is probably due to the lack of good present-day analogues for the cedar/heath pollen association (Fig. 6). 


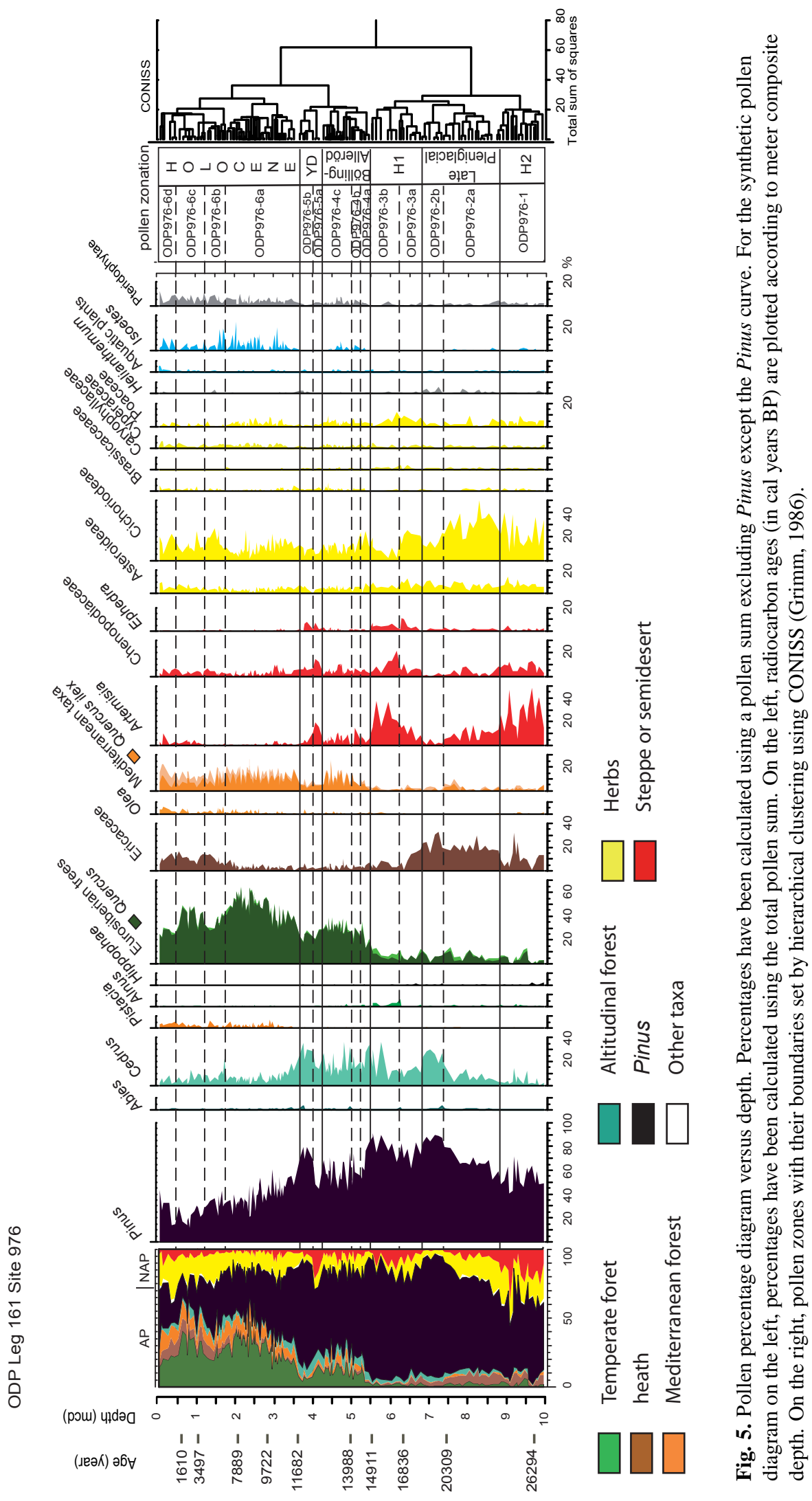


Table 2. Chronostratigraphy and description of the ODP Site 976 pollen zones with their main representative biomes deduced from pollen association.

\begin{tabular}{|c|c|c|c|}
\hline Chronostatigraphy & Pollen zone & Pollen signature & Main biome \\
\hline \multirow[t]{4}{*}{ Holocene } & ODP 976-6d & $\begin{array}{l}\text { Increase in Pinus (30\%), Mediterranean taxa }(20 \%) \text {, } \\
\text { Ericaceae }(15 \%) \text { and Cichoriodeae }(25 \%) \\
\text { Peak in Artemisia }(10 \%) \\
\text { Decrease in Quercus }(<30 \%)\end{array}$ & Warm mixed forest \\
\hline & ODP 976-6c & $\begin{array}{l}\text { Oscillations in Quercus }(30-50 \%) \\
\text { Reappearance of Artemisia in low percentages, low } \\
\text { percentages in Cichoriodeae }(<10 \%) \text { and Ericaceae } \\
\text { lower than } 10 \%\end{array}$ & $\begin{array}{l}\text { Warm mixed forest } \\
\text { Temperate deciduous forest }\end{array}$ \\
\hline & ODP 976-6b & $\begin{array}{l}\text { Increase in Ericaceae }(15 \%) \text { and Cichoriodeae }(25 \%) \\
\text { Quercus decrease }(<30 \%)\end{array}$ & $\begin{array}{l}\text { Warm mixed forest } \\
\text { Temperate deciduous forest }\end{array}$ \\
\hline & ODP 976-6a & $\begin{array}{l}\text { Regular decrease in Pinus }(70 \rightarrow 30 \%) \text { and Cedrus } \\
(30 \rightarrow 5-10 \%) \\
\text { Higher abundance of Quercus }(40-60 \%) \text { and increase } \\
\text { in Mediterranean taxa }(10-15 \%) \\
\text { Regular presence of Pistacia and Olea } \\
\text { Isoetes regularly abundant }\end{array}$ & $\begin{array}{l}\text { Warm mixed forest } \\
\text { Temperate deciduous forest } \\
\text { Climatic optimum }\end{array}$ \\
\hline \multirow[t]{2}{*}{ Younger Dryas } & ODP $976-5 b$ & $\begin{array}{l}\text { Pinus }(70 \%) \\
\text { Increase in Cedrus }(30 \%) \\
\text { Low representation in Quercus }(<20 \%) \\
\text { Decrease in Artemisia and Chenopodiaceae and } \\
\text { persistance of Ephedra } \\
\text { Pteridophytae }(5-10 \%)\end{array}$ & $\begin{array}{l}\text { Temperate deciduous } \\
\text { forest }\end{array}$ \\
\hline & ODP 976-5a & $\begin{array}{l}\text { Pinus }(<50 \%) \\
\text { Increase in all semidesert taxa }(\text { Artemisia }-20 \% \text {, } \\
\text { Ephedra }-5 \% \text {, Chenopodiaceae }-15 \%) \text {, } \\
\text { Decrease in all trees (Cedrus }<10 \%, \text { Quercus }<20 \%)\end{array}$ & $\begin{array}{l}\text { Temperate decidupus forest } \\
\text { Steppe }\end{array}$ \\
\hline $\begin{array}{l}\text { Bölling/Allerød } \\
\text { Allerød }\end{array}$ & ODP $976-4 \mathrm{c}$ & $\begin{array}{l}\text { Pinus }(40-60 \%) \\
\text { Increase in temperate }(30 \%) \text { and } \\
\text { Mediterranean taxa }(15 \%) \\
\text { Decrease in semi desert }(<15 \%) \\
\text { Isoetes in low percentages }(1-5 \%)\end{array}$ & $\begin{array}{l}\text { Temperate deciduous forest } \\
\text { Warm mixed forest }\end{array}$ \\
\hline Older Dryas & ODP 976-4b & $\begin{array}{l}\text { Pinus }(40-60 \%) \\
\text { Decrease in temperate taxa } \\
\text { Slight increase in semi desert }(<15 \%)\end{array}$ & Warm steppe \\
\hline Bölling & ODP 976-4a & $\begin{array}{l}\text { Pinus }(40-60 \%) \\
\text { Increase in temperate }(30 \%) \text { and } \\
\text { Mediterranean taxa }(15 \%) \\
\text { Decrease in semi desert }(<15 \%)\end{array}$ & $\begin{array}{l}\text { Temperate deciduous forest } \\
\text { Warm mixed forest }\end{array}$ \\
\hline \multirow[t]{2}{*}{ Oldest Dryas-H1 } & ODP 976-3b & $\begin{array}{l}\text { Pinus }(70-80 \%) \\
\text { Low percentages in Quercus and temperate taxa } \\
(<10 \%) \text {, presence of pioneers (Alnus) } \\
\text { Decrease in Ericaceae }(15 \rightarrow 5 \%) \\
\text { Increase in semi desert associations (Artemisia } \\
20-40 \%) \text {, Chenopodiaceae }(10-20 \%) \text {, } \\
\text { Ephedra }(5-10 \%) \\
\text { Cichoriodeae decrease }(20 \rightarrow<10 \%)\end{array}$ & Steppe \\
\hline & ODP 976-3a & $\begin{array}{l}\text { Pinus }(60-70 \%) \\
\text { Cichoriodeae abundant }(25 \%) \text {, Poaceae }(5-10 \%) \\
\text { Low percentages in temperate and } \\
\text { Mediterranean taxa }(<10 \%) \\
\text { Ericaceae decrease }(20-10 \%) \\
\text { Cedrus decrease }(20 \rightarrow<10 \%)\end{array}$ & Warm steppe \\
\hline \multirow[t]{2}{*}{ Late pleniglacial } & ODP 976-2b & $\begin{array}{l}\text { Pinus }(80 \%) \\
\text { Low percentages in temperate and } \\
\text { Mediterranean taxa }(<10 \%) \\
\text { Cedrus abundant }(10-25 \%) \\
\text { Ericaceae abundant }(15-25 \%) \\
\text { Semi desert elements in low representation } \\
\text { (Artemisia }<10 \%, \text { Ephedra }<5 \% \text {, } \\
\text { Chenopodiaceae }<10 \%) \\
\text { Cichoriodeae }(15 \%)\end{array}$ & Temperate deciduous forest \\
\hline & ODP 976-2a & $\begin{array}{l}\text { Pinus }(60 \%) \\
\text { Cedrus }(<10 \%) \\
\text { Low percentages in temperate and } \\
\text { Mediterranean } \mathrm{f} \text { taxa }(<10 \%) \\
\text { Ericaceae abundant }(15-25 \%) \\
\text { Cichoriodeae in high percentages }(20-40 \%)\end{array}$ & Steppe \\
\hline $\mathrm{H} 2$ & ODP 976-1 & $\begin{array}{l}\text { Pinus }(35-60 \%) \\
\text { Low percentages in temperate and } \\
\text { Mediterranean taxa }(<10 \%) \\
\text { Ericaceae }(10-30 \%) \\
\text { semi desert taxa abundant (Artemisia } 20-50 \%) \text {, } \\
\text { Chenopodiaceae }(5-15 \%) \text {, Ephedra }(1-5 \%) \\
\text { Cichoriodeae }(15-35 \%) \text {, Poaceae }(5 \%)\end{array}$ & Steppe \\
\hline
\end{tabular}




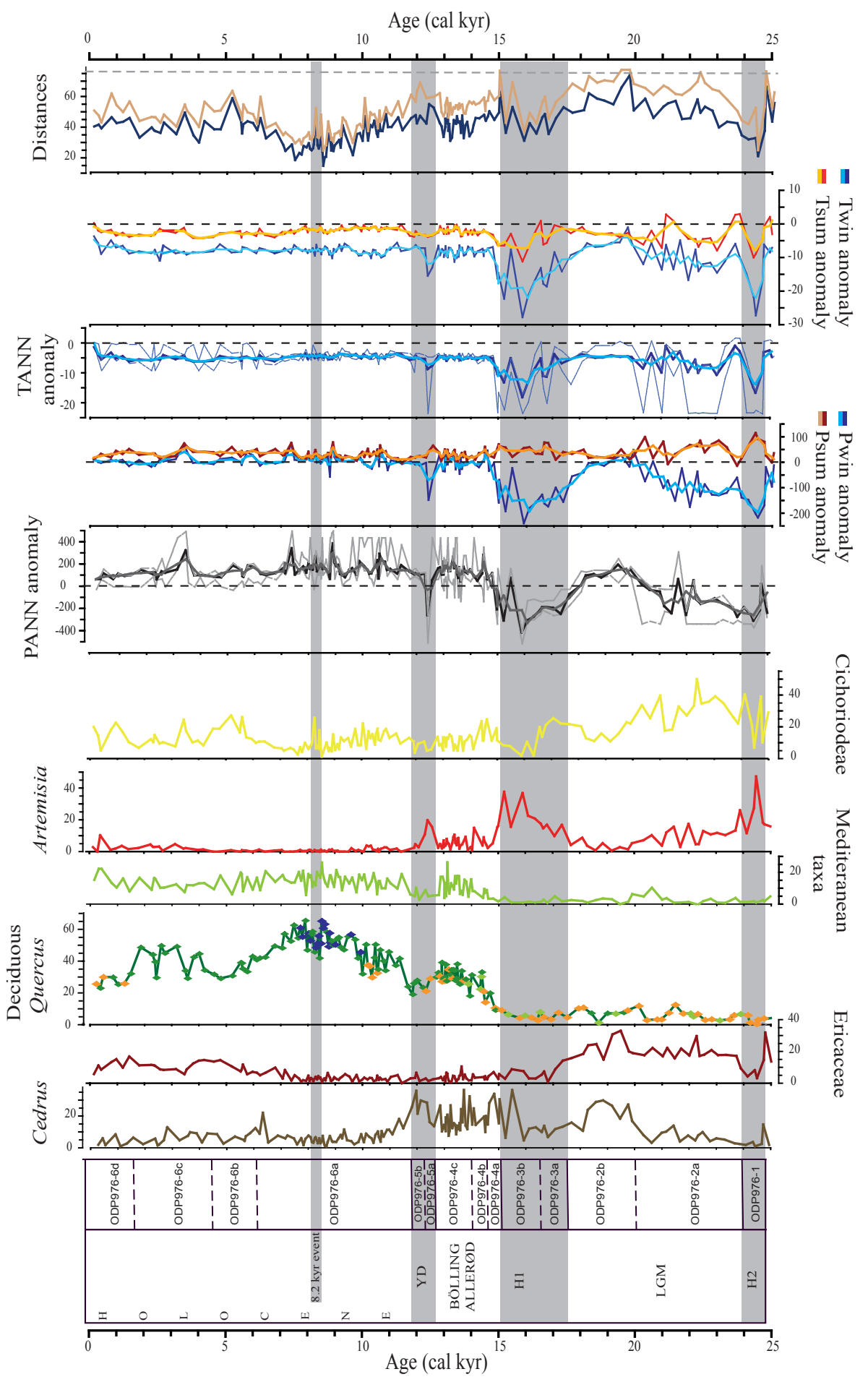

Fig. 6. ODP Site 976 main pollen percentage curves (Cedrus, Ericaceae, Quercus, Mediterranean taxa, Artemisia, Chenopodiaceae, Cichorioideae). Anomaly curves versus present-day for Pann (annual precipitation), Pwin (winter precipitation) and Psum (summer precipitation), Tann (annual temperature), Tsum (mean temperature of the warmest month), Twin (mean temperature of the coldest month) from MAT method (dark color curves: MAT values; light color curves: 3 point smoothed curves). The dissimilarity index (Chord distance) measures the quality of the reconstruction through the modern analogues selection. On the top, the calculated distances of the first (blue) and the last (orange) of the best analogues selected. The dotted line marks the threshold value (here 77.9) obtained from the Monte Carlo method defined in Guiot (1990). Biomes deduced from MAT method are plotted on the Quercus percentage curve (warm mixed forest in dark blue, temperate deciduous forest in green, warm steppe in yellow-orange and cold steppe in olive green). 


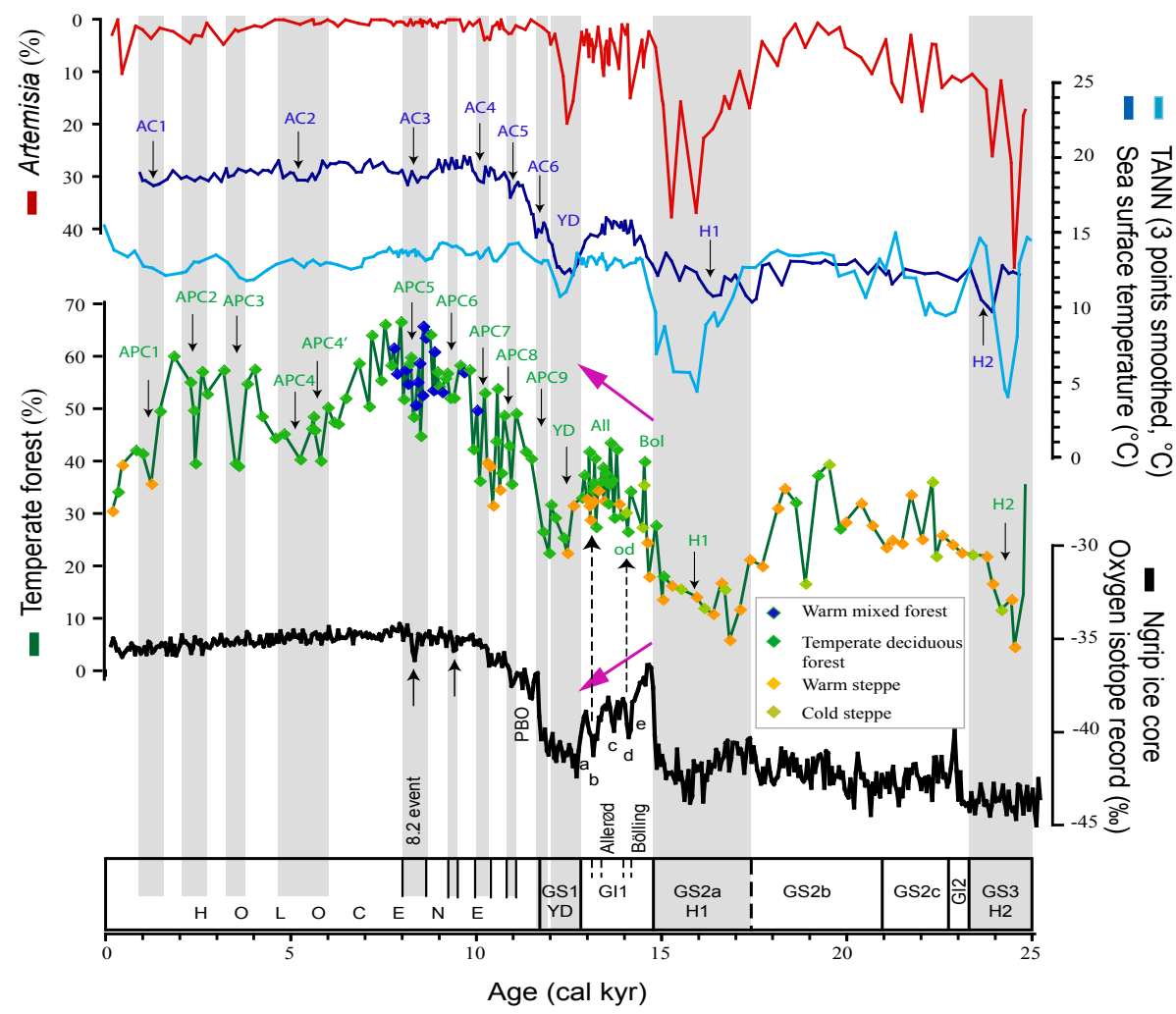

Fig. 7. Correlation between the climate events which occurred during the Last Deglaciation and the Holocene between the Alboran Sea pollen ODP Site 976 record and associated TANN reconstruction (3-point smoothed), the Alboran Sea alkenone SST record (MD 95-2043, Cacho et al., 2001) and the Greenland ice core record (Ngrip, Johnsen et al., 2001). Events are underlined in grey and with black arrows. trends are represented with pink arrows.

\subsection{Heinrich event 1}

Between 17000 and $15000 \mathrm{cal} \mathrm{yr}$ BP (pollen zone 3, Fig. 5, Table 2), a large development of Artemisia, Chenopodiaceae and Ephedra associated first with Asteraceae indicate an expansion of steppe or semi-desert (Table 2, Fig. 5). Such change in the vegetation around $15000 \mathrm{yr}$ BP has been clearly evidenced and often attributed to the Oldest Dryas (GS-2) event, in the south-west as well as in other parts of the Mediterranean region (e.g. Pons and Reille, 1988; Watts et al., 1996; Combourieu Nebout et al., 1998, 2002; Allen et al., 2002; Peñalba et al., 1997; Turon et al., 2003; Naughton et al., 2007; Fletcher and Sánchez Goñi, 2008; Bordon et al., 2009). This corresponds with increased dryness over the Mediterranean and especially over the Alboran Sea borderlands. This semi-desert expansion is correlated in the marine environment to a peak in the foraminifer Neogloboquadrina pachyderma left coiling indicating a SST cooling (Combourieu Nebout et al., 2002). This cold and dry event is consistent with the H1-Oldest Dryas event as recorded in other marine records off Iberian peninsula (e.g. Fletcher and Sánchez Goñi, 2008; Turon et al., 2003; Naughton et al., 2007). A maximum in cedar percentages reflects the devel- opment of a conifer forest at high elevation in the mountains that probably implies an increasing input from the south (Magri et al., 2002). As during $\mathrm{H} 2$, the reconstructed biomes from pollen data correspond to an alternation of warm and cold steppe/temperate grassland. Reconstructed annual temperature and precipitation show very cold conditions (Twin anomalies: around $-20^{\circ} \mathrm{C}$, Tsum anomalies: around $-8^{\circ} \mathrm{C}$, Pwin anomalies: -200 to $-300 \mathrm{~mm}$, Psum anomalies: 0 to $50 \mathrm{~mm}$ ) (Fig. 6). The annual temperature change reconstructed here fits remarkably well that of the alkenone-based SST record in the nearby MD 95-2043 marine core (Cacho et al., 2001; Pérez Folgado et al., 2004) (Fig. 7). However, the continental temperature values show a more abrupt decrease and are colder than the alkenone and foraminifer-based SST in the Mediterranean (Cacho et al., 2001; Kallel et al., 1997; Rohling et al., 1998; Pérez Folgado et al., 2003).

\subsection{Bölling-Allerød}

From 14700 to 12500 cal yr BP (pollen zone 4, Fig. 5, Table 2), the first large increase in deciduous (mainly Quercus) and Mediterranean taxa corresponds to the Bölling-Allerød interstadial (GI-1). During this period, Cedrus is abundant (15-20\%), while, among the herbs, the Cichoriodeae remain 
present in noticeable percentages (15-20\%) and semi-desert taxa such as Artemisia strongly decrease (Table 2, Fig. 5). Such an association implies settling of the forest into altitudinal belts in the Betic and Rif Arc mountains with a probable enhanced wind input from the south (Magri and Parra, 2002; Bout-Roumazeille et al., 2007). The development of the Mediterranean oak forest at the expense of semidesert formations is largely recognized in all the Mediterranean records. The ODP Site 976 diagram may then be easily correlated to the well known Padul peat bog pollen diagram from Southern Spain (Pons and Reille, 1988). Nevertheless, the Mediterranean taxa are less represented in marine than in continental records. This discrepancy is probably due to the location of the Padul peat bog at 785 m elevation in the altitudinal range of the Quercus ilex sclerophyllous forest (Barbero et al., 1992). Climatic reconstructions reveal temperature and precipitation values comparable to those depicted during the Holocene. The biome reconstructions clearly indicate temperate deciduous forest. However, some samples are still associated with a steppe biome (Figs. 5 and 6), and could indicate the occurrence of rapid and abrupt climate events during the Late glacial. Two clear warming episodes are depicted by a forest development from 14800 to $14120 \mathrm{cal} \mathrm{yr} \mathrm{BP}$ and from 13800 to $12800 \mathrm{cal} \mathrm{yr} \mathrm{BP}$. They may be interpreted as the well-known Bölling and Allerød warming periods respectively (Figs. 5 and 6), which are described in Europe and the Mediterranean records (e.g. Magny et al., 2006; Drescher-Schneider et al., 2007; Kotthoff et al., 2008b). These warm episodes are separated by a rapid cold oscillation from 14120 to 13800 cal yr BP (Fig. 5 and Table 3, "od" event) indicated by a weak decrease in forest cover that may be related to the Older Dryas or GI-1d event (Wohlfart, 1996; Bjork et al., 1998; Lowe et al., 2008). The chronology of ODP Site 976 events is in agreement with both North GRIP and GISP chronozones GI-a to c, $d$ and e (Table 3, Rasmussen et al., 2006, 2007; Lowe et al., 2008). Nevertheless, our pollen record does not permit to distinguish the GI-1a, b, c succession, although we clearly see biome changes from temperate deciduous forest to steppe during the Allerød interstadial at around $13200 \mathrm{cal} \mathrm{yr} \mathrm{BP}$ that may be related to GI-1b (Fig. 7). The Bölling interstadial appears slightly less warm than the Allerød interstadial, as recorded by a weaker development of temperate forest (Fig. 7). It suggests a warming trend from Bölling to Allerød which has been also evidenced in the stalagmite oxygen isotope record from Southern France (Genty et al., 2006). Such a trend contrasts to the cooling recorded by the North GRIP and GISP ice core records and the Mid-European lake isotope signal which show a warmer Bölling followed by a regular trend decreasing intensity of the Allerød warm events (Rasmussen et al., 2006, 2007; Lowe et al., 2008; NGrip members, 2004; Johnsen et al., 2001; von Grafenstein et al., 1999). Therefore, the ODP Site 976 results support the evidence of a general north to south climatic contrast during the Bölling/Allerød period showing a cooling in Greenland and Northern Europe and a climate stability or warming in the Southern Europe and North Africa (Genty et al., 2006).

\subsection{Younger Dryas}

Between 12500 and 11750 cal yr BP (pollen zone 5, Fig. 5, Table 2), an increase of Artemisia and semi-desert taxa suggests the return to cold conditions related to the Younger Dryas event (YD) (Table 1, Fig. 5). This event is recorded throughout the Mediterranean by many proxies from both continental and marine sites (e.g. Pons and Reille, 1988; Lamb et al., 1989; Watts et al., 1996; Combourieu Nebout et al., 1998, 2002; Allen et al., 1996, 2002; Peñalba et al., 1997; Turon et al., 2003; Naughton et al., 2007; Kotthoff et al., 2008b; Fletcher and Sánchez Goñi, 2008; Bordon et al., 2009; Dormoy et al., 2009). This period may be divided into two parts: a very dry period at the beginning (12500 to $12200 \mathrm{yr}$ ) which corresponds to the increase of Artemisia and a more humid period (12200 to 11750) at least at mid to high elevation, indicated by the correlative presence of Artemisia semi-desert and cedar forest together with a slight increase of Quercus forest (Fig. 5).

The biomisation indicates a steppe at the beginning of the YD and a temperate deciduous forest during the second part. During the first Artemisia semi-desert phase, cold and dry conditions are reconstructed for all climate parameters (Fig. 6). Finally, Twin and Pwin increase at the time of cedar presence in vegetation. These results suggest storage of fresh water in continental ice sheet during the dry and cold phase of the Younger Dryas whereas the following humid period may reflect enhanced precipitation possibly due to a more efficient hydrological cycle. Alternatively, it could also correspond to a latitudinal shift of the Westerlies northward during the early phase and to the south afterwards that may be linked to particular atmospheric configurations such as alternation between positive and negative NAO situations.

\subsection{Holocene}

In the Alboran Sea borderlands, the onset of the Holocene (pollen zone 6, Fig. 5, Table 1) is clearly detected after $11750 \mathrm{cal}$ yr BP by the large expansion of the forest mainly composed of deciduous Quercus in association with Mediterranean sclerophyllous taxa (mainly $Q$. ilex-type and Pistacia) (Table 2, Fig. 5). Such a vegetation change is classically observed at the beginning of Holocene in the Mediterranean region although the forest expansion is delayed by up to three millennia in some marginal areas due to moisture deficiency or anthropogenic activity (e.g. Pons and Reille, 1988; Lamb et al., 1989; Watts et al., 1996; Combourieu Nebout et al., 1998, 2002; Allen et al., 1996, 2002; Peñalba et al., 1997; Turon et al., 2003; Naughton et al., 2006; Fletcher and Sánchez Goñi, 2008; Bordon et al., 2009; Jalut et al., 2009; Tzedakis, 2007; Tinner et al., 2009). This marks the progressive onset of the present-day altitudinal vegetation belts and 
Table 3. Age comparison between events from ODP 976 record and Greenland records during the Bölling/Allerød period.

\begin{tabular}{llll}
\hline \multicolumn{2}{c}{ Ngrip and Grip $^{\mathrm{a}, \mathrm{b}}$} & \multicolumn{2}{c}{ Alboran Sea } \\
\hline Events & Age in cal kyr BP & Pollen event $^{\mathrm{c}}$ & Age in cal kyr BP \\
\hline GS-1 & $12.896^{\mathrm{a}, \mathrm{b}}-11.703^{\mathrm{a}, \mathrm{b}}$ & Younger Dryas & $12.8-11.75$ \\
GI-1a & $13.099^{\mathrm{b}}-12.896^{\mathrm{a}, \mathrm{b}}$ & Allerød & $13.8-12.8$ \\
GI-1b & $13.311^{\mathrm{b}}-13.099^{\mathrm{b}}$ & interstadial & \\
GI-1c & $13.954^{\mathrm{b}}-13.311^{\mathrm{b}}$ & & $14.12-13.8$ \\
GI-1d & $14.075^{\mathrm{a}, \mathrm{b}}-13.954^{\mathrm{b}}$ & Older dryas stadial (od event) & $14.8-14.12$ \\
GI-1e & $14.692^{\mathrm{a}, \mathrm{b}}-14.075^{\mathrm{a}, \mathrm{b}}$ & Bolling interstadial & 14 \\
\hline
\end{tabular}

${ }^{\mathrm{a}}$ Rasmussen et al. (2006); ${ }^{\mathrm{b}}$ Lowe et al. (2008); ${ }^{\mathrm{c}}$ this work

Mediterranean climate. This forest expansion is contemporaneous with the shift in planktonic $\delta^{18} \mathrm{O}$ towards light values which reflects the climate improvement in the marine environments at the beginning of the Holocene (Combourieu Nebout et al., 1998, 1999, 2002). A parallel change is detected by the alkenone and foraminiferal-based SST records in the nearby MD 95-2042 core (Cacho et al., 2001; Pérez Folgado et al., 2002). In comparison, the amplitude of MAT annual temperature rise is lower than SST shift. This can be partly due to the $\sim 3^{\circ} \mathrm{C}$ bias on the MAT Twin values previously shown (Fig. 7). The maximum extension of Quercus forest marks the optimum climatic conditions of the Holocene between 9000 and 7000 cal yr BP. However, this interval is interrupted by a forest decrease event at around 8000 cal yr BP that can be correlated to the $8.2 \mathrm{ka}$ event. The biome assignment shows an alternating of temperate, deciduous forest and warm mixed forest, especially around the $8.2 \mathrm{ka}$ event. The climate reconstruction shows warm and humid conditions (Fig. 6); the wetness is also depicted by the increase in fresh water plants input (Fig. 5). The annual temperature (between 0 and $-5^{\circ} \mathrm{C}$ ) and precipitation (between 0 and $100 \mathrm{~mm}$ ) anomalies are consistent with the reconstructions obtained from southern Spanish records by the inverse modelling method for the mid-Holocene period (i.e. 6000 cal yr BP; Wu et al., 2007; Brewer et al., 2007) (Fig. 6).

After 7000 cal yr BP, a substantial decrease of the forest cover marks the upper late Holocene cooling trend that is not clearly expressed with the climate parameters changes (Fig. 6). The period between 4000 and 1500 cal yr BP, is marked by abrupt forest cover expansion/regression episodes. In the younger samples (younger than $1500 \mathrm{yrs}$ ), semi-desert taxa and especially Artemisia increase again, suggesting the recent change in vegetation cover probably related to anthropogenic impact.

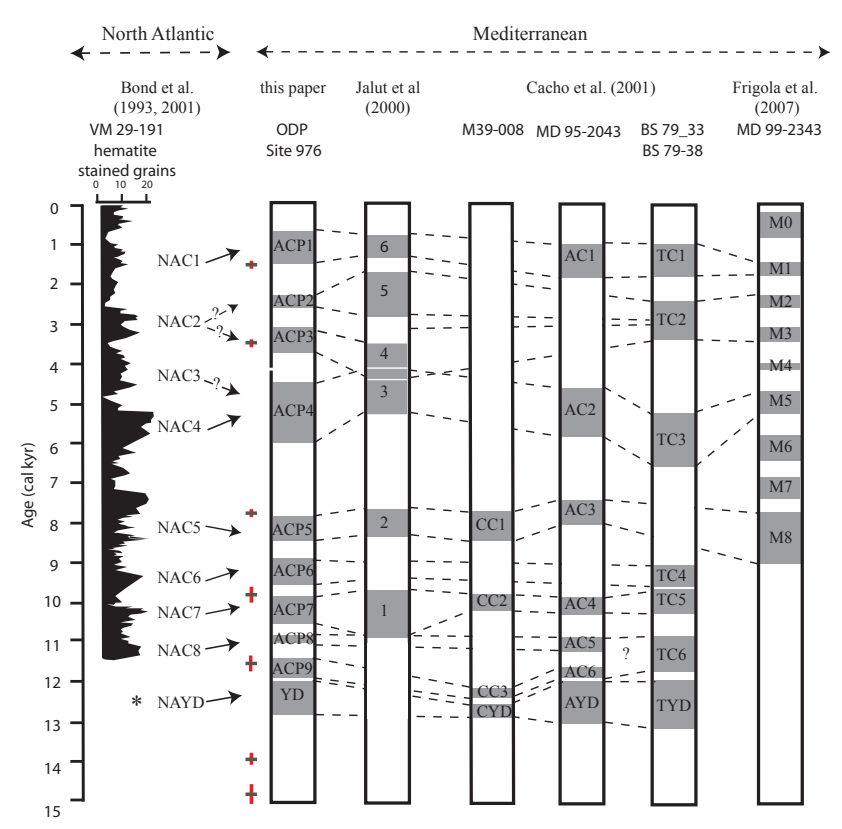

Fig. 8. Correlation between the Alboran Sea pollen events from ODP Site 976 record, North Atlantic cold events (Bond et al., 1993), aridification events in the continental sites (Jalut et al., 2000), and Mediterranean marine events from the Adriatic Sea, Tyrrhenian Sea and Gulf of Cadiz (Cacho et al., 2001) and from the oxygen isotope record off the Balearic islands (Frigola et al., 2007).

The general warming then cooling trends of the Holocene are interrupted by several rapid oscillations depicted by the temperate forest curve which may be interpreted as shortlived climate events at 11.95-11.4, 11-10.8, 10.5-9.8, 9.68.9, 8.5-7.9, 6-4.5, 3.7-3.1, 2.6-2.3 and 1.5-0.7 ka, ACP1 to 8 (Tables 3, 4, Figs. 7 and 8). Similar changes in vegetation composition during the Holocene have also been documented in the Italian Monticchio series (Allen et al., 2002) and in the Iberian Peninsula (Jalut et al., 2000). Even if unnoticeable increase in steppic vegetation occurred during ODP Site 976 events, some of the temperate forest reduction events may be 
Table 4. Age comparison between the Alboran Sea pollen events from ODP Site 976 record, the North Atlantic cold events (Bond et al., 1993), the aridification events in the continental sites (Jalut et al., 2000), and with Mediterranean marine events from alkenone record in Adriatic Sea, Tyrrhenian Sea and Gulf of Cadix (Cacho et al., 2001) and from the oxygen isotope record off Balearic islands (Frigola et al., 2007).

\begin{tabular}{|c|c|c|c|c|c|c|}
\hline \multirow{3}{*}{$\begin{array}{l}\text { North Atlantic } \\
\text { Cold event }^{\mathrm{a}}\end{array}$} & \multicolumn{5}{|c|}{ Mediterranean } & \multirow{3}{*}{$\frac{\delta^{18} \mathrm{O} \text { events }}{\mathrm{e}}$} \\
\hline & \multirow[t]{2}{*}{ Pollen Events ${ }^{b}$} & \multirow[t]{2}{*}{ Aridification events ${ }^{c}$} & \multicolumn{3}{|c|}{ SST Events ${ }^{\mathrm{d}}$} & \\
\hline & & & Gulf of Cadiz & Alboran Sea & Tyrrhenian Sea & \\
\hline 1 & APC1 & 6 & - & $\mathrm{AC} 1$ & TC1 & M1 \\
\hline 1.4 & $0.7-1.5(1.1)$ & $0.75-1.3$ & & $1.01-1.9$ & $1-1.91$ & $1.4-1.8$ \\
\hline 2 & APC 2 & 5 & - & - & $\mathrm{TC} 2$ & M2 \\
\hline 2.8 & $2.3-2.6(2.45)$ & $1.7-2.8$ & & & $2.5-3.45$ & $2.3-2.6$ \\
\hline- & APC 3 & & - & - & - & M3 \\
\hline & $3.14-3.77(3.36)$ & 4 & & & & $3.1-3.4$ \\
\hline 3 & & $3.4-4.3$ & - & - & - & M4 \\
\hline 4.3 & ACP 4 & & & & & $4-4.2$ \\
\hline 4 & $4.5-6(5.2)$ & 3 & & $\mathrm{AC} 2$ & TC3 & M5 \\
\hline 5.9 & & $4.2-5.3$ & & $4.75-5.94$ & $5.28-6.58$ & $4.7-5.3$ \\
\hline 5 & APC 5 & 2 & $\mathrm{CC} 1$ & $\mathrm{AC} 3$ & - & M8 \\
\hline 8.2 & $7.9-8.5(8.2)$ & $7.6-8.4$ & $7.8-8.25$ & $7.56-9.08$ & & $7.8-9$ \\
\hline 6 & APC 6 & $?$ & - & - & TC4 & - \\
\hline 9.5 & $9.6-8.9(9.35)$ & $9-9.5$ & & & $9.13-9.62$ & \\
\hline 7 & APC 7 & 1 & $\mathrm{CC} 2$ & $\mathrm{AC} 4$ & TC5 & - \\
\hline 10.3 & $9.8-10.5$ (10.35) & $9.7-10.9$ & $9.9-10.2$ & $9.95-10.34$ & $9.62-10.38$ & \\
\hline 8 & APC 8 & & - & AC5 & - & - \\
\hline 11.1 & $10.8-11(10.9)$ & & & $10.95-11.21$ & & \\
\hline- & APC 9-YD1 & & $\mathrm{CC} 3$ & AC6 & TC6 & - \\
\hline & $11.4-11.75$ (11.57) & & $12.2-12.4$ & $11.65-11.9$ & $10.9-11.78$ & \\
\hline YD & YD2 & & CYD & AYD & TYD & - \\
\hline 12.5 & $11.75-12.8(12.37)$ & & $12.6-12.9$ & $12-13.1$ & $12-13.09$ & \\
\hline
\end{tabular}

${ }^{\mathrm{a}}$ Bond et al. (1997); ${ }^{\mathrm{b}}$ this work; ${ }^{\mathrm{c}}$ Jalut et al. (2002); ${ }^{\mathrm{d}}$ Cacho et al. (2001), ${ }^{\mathrm{e}}$ Frigola et al. (2007)

chronologically linked to the Holocene aridification episodes documented in the continental pollen records from Southern Spain. Therefore APC 1, 2, 4, 5 and 7 may be correlated to the aridification events $6,5,3,2$ and 1 noted by Jalut et al. (2000) (Table 4, Fig. 8).

These rapid and repetitive forest cover fluctuations do not correspond to abrupt changes in climate parameters as shown by the weak changes in MAT reconstructed temperature (Tann, Twin) and/or in precipitation (Pann, Pwin) anomalies (Figs. 6 and 7). This is particularly evidenced for the $8.2 \mathrm{ka}$ event which is marked by a larger decrease in temperate and humid forest associated with increased Cichoriodeae and only represented by weak changes in reconstructed climate parameters (Fig. 7). Nevertheless, the strong decrease in temperate, humid forest that marks the $8.2 \mathrm{ka}$ event may be linked to a decrease in humidity (Dormoy et al., 2009) that correlates to low lake-levels in western and to the aridification event 2 Mediterranean (Jalut et al., 2000; Magny et al., 2003; Lamb et al., 1995).

The variability of vegetation cover may also be correlated to marine environmental changes recorded by the alkenonebased SST events in other cores located in the Gulf of Cadiz, Alboran and Tyrrhenian Sea (Cacho et al., 2001) (Figs. 7 and 8 ) and with $\delta^{18} \mathrm{O}$ events detected in Balearic basin (Frigola et al., 2007) (Table 4). A tentative correlation between west Mediterranean vegetation events and these marine cold events is presented in Fig. 5. Taking into account the different chronological framework, each ODP forest event can be tentatively correlated to west Mediterranean marine cold events. However, a comparison between the Alboran Sea pollen and alkenone-based SST records shows that more events are expressed on the continent (Fig. 7). Thus, ACP 
6, 3 and 2 are absent in the Alboran Sea alkenone-based $\mathrm{SST}$ record. If we look only at the pollen-inferred TANN and alkenone-based SST curves, this discrepancy disappears (Fig. 7). This may be related to the combined temperature and precipitation influence on the Alboran Sea borderland vegetation which is particularly controlled by moisture availability.

As the North Atlantic influence modulates the present-day western Mediterranean climate variability (Lionello et al., 2006), the nine pollen events detected by the ODP Site 976 record may also be linked to the North Atlantic Holocene cold events (Bond et al., 1993, 2001). We present here a eventual correlation (Fig. 8, Table 4). According to our chronology, ACP 1, 2 and 4 to 8 may be related to Bond events 1 to 3 and 5 to 8 (Fig. 8). ACP 4 could include two Bond events, 3 and 4 probably, because, at the time of Bond event 3 , only a very slight change appears in our record. This discrepancy is probably due to the lack of ${ }^{14} \mathrm{C}$ dates within the 7.8-3.2 ka interval that reduces age constrains at time of ACP 4 event (Figs. 2 and 8). In fact, this event corresponds here simultaneously to an increase in Ericaceae and a minimum representation of Quercus (Figs. 5 and 6) resulting only in a slight decrease in our temperate forest curve at around $4500 \mathrm{yr}$ (Fig. 7). During the Holocene, beside being represented on their own chronological scale, the timing of ACP events is very consistent with the North Atlantic Bond events (Bond et al., 1993, 2001) and Mediterranean climate events defined both in marine and continental series (Cacho et al., 2001; Frigola et al., 2007; Jalut et al., 2000, 2009) (Fig. 8). This suggests a very rapid response of Mediterranean vegetation to short-term climate forcing.

These repetitive short-lived events recorded in the ODP pollen data reveal the high variability of continental climate in the Mediterranean region during the Holocene and confirm the far-reaching impact of the North Atlantic cold events on both marine data (Cacho et al., 2001; Frigola et al., 2007) and continental vegetation of the whole Mediterranean (Allen et al., 2002; Jalut et al., 2000, 2009). ODP Site 976 results highlight the main control of precipitation on Mediterranean vegetation changes, that reflect the Ocean-Atmosphere coupling through the apparent link between North Atlantic SSTs and atmospheric configuration (Cacho et al., 2001).

\section{Conclusions}

In order to investigate the vegetation and climatic variability during the last 25000 years in the Mediterranean region, we have established a marine pollen record (ODP Site 976) from the Alboran Sea and quantitatively estimated the climatic changes using the Modern Analog Technique.

Beforehand, we have tested the reliability of this approach in reconstructing the climatic parameters from marine pollen spectra in using 22 Atlantic and Mediterraneean core-top pollen samples. An adequate consistency between the present day observed and MAT estimations is especially shown for Tsum, Psum and Pann values. Nevertheless, MAT winter temperatures seem to be underestimated by few degrees and winter precipitation overestimated by less than one hundred millimeters. Although future studies including a greater number of core-top samples are necessary, the MAT appears already as a valuable approach to estimate the past climatic changes on land from marine Mediterranean pollen records.

The high-temporal resolution pollen record ODP Site 976, pollen-based quantitative climate reconstruction and biomisation show that Mediterranean vegetation changes have been clearly modulated by short-term and long-term variability of the North Atlantic during the last deglaciation and the Holocene. As in other western Mediterranean cores, the ODP Site 976 pollen record shows drastic cool and dry conditions which are correlated to the refreshment of Mediterranean sea surface temperature and coeval with Heinrich events 2 and 1. During the Bölling/Allerød period, two warm episodes surround a cooling, which represent the climatic succession of Bölling, Older Dryas and Allerød, with a cool trend from Bölling to Allerød. The Younger Dryas event may be divided into two parts: a very dry period followed by a more humid interval at least at mid to high elevation. Recurrent Holocene declines of forest cover on the Alboran Sea borderlands correlate with the continental aridification events and the Mediterranean SST coolings. They also are timely correlated to the Holocene North Atlantic cold events. This suggests the rapid response of Mediterranean vegetation to Holocene short-time climate events and reflects the large ocean-atmosphere coupling.

Acknowledgements. We thank the Ocean Drilling Program for material from core ODP leg 161 Site 976. This work has been supported by programs associated with the French CNRS, INSU and ANR through PNEDC, PICC, IDEGLACE and LAMA research projects. We thank Elisabeth Michel, Viviane Bout-Roumazeilles and Sarah Ivory for their helpful comments. We thank also J. P. Cazet and M. H. Castera for help with the processing of samples. This is LSCE contribution no. 4011.

Edited by: J. Guiot

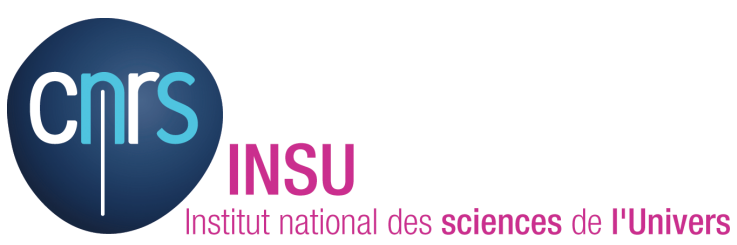

The publication of this article is financed by CNRS-INSU. 


\section{References}

Allen, J. R. M., Huntley, B., and Watts, W. A.: The vegetation and climate of northwest Iberia over the last $14000 \mathrm{yr}$, J. Quaternary Sci., 11, 125-147, 1996.

Allen, J. R. M., Watts, W. A., McGee, E., and Huntley, B.: Holocene environmental variability - the record from Lago Grande di Monticchio, Italy, Quatern. Int., 88, 69-80, 2002.

Antonioli, F., Silenzi, S., and Frisia, S.: Tyrrhenian Holocene palaeoclimate trends from spelean serpulids, Quaternary Sci. Rev., 20, 1661-1670, 2001.

Barbero, M., Loisel, R., and Quézel, P.: Biogeography, ecology and history of Mediterranean Quercus ilex ecosystems, Vegetatio, 99-100, 19-34, 1992.

Barbero, M., Quézel, P., and Rivas Martinez, S.: Contribution à l'étude des groupements forestiers et préforestiers du Maroc, Phytoenologia, 9, 311-412, 1981.

Bard, E.: Geochemical and geophysical implications of the radiocarbon calibration, Geochim. Cosmochim. Ac., 62, 2025-2038, 1998.

Bard, E., Arnold, M., Hamelin, B., and Tisnerat-Isaborde, N.: Radiocarbon calibration by means of mass spectrometric ${ }^{230} \mathrm{Th} /{ }^{234} \mathrm{U}$ and ${ }^{14} \mathrm{C}$ ages of corals: An updated data base including samples from Barbados Mururoa and Tahiti, in: Calibration 1998: Radiocarbon, edited by: Stuiver, M., 40, 1085-1092, 1998.

Beaudouin, C., Jouet, G., Suc, J.-P., Berne, S., and Escarguela, G.: Vegetation dynamics in southern France during the last 30 ky BP in the light of marine palynology, Quaternary Sci. Rev., 26, 1037-1054, 2007.

Benabib, A.: Bref aperçu sur la zonation altitudinale de la végétation climatique du Maroc, Ecol. Medit., 8(1-2), 301-315, 1982.

Benabid, A.: Flore et ecosystems du Maroc, Editions Ibis Press, Paris, France, 359 pp., 2000.

Björk, S., Walker, M. J. C., Johnsen, S. J., Knudsen, K. L., Lowe, J., Wohlfart, B., and Intimate members: An event stratigraphy for the last termination In the North Atlantic region based on the Greenland ice-core record: a proposal by the intimate group., J. Quaternary Sci., 4, 283-292, 1998.

Bond, G., Broecker, W., Johnsen, S., McManus, J., Labeyrie, L., Jouzel, J., and Bonani, G.: Correlations between climate records from North Atlantic sediments and Greenland ice, Nature, 365, 143-147, 1993.

Bond, G., Showers, W., Cheseby, M., Lotti, R., Almasi, P., deMenocal, P., Priore, P., Cullen, H., Hajdas, H., and Bonani, G.: A pervasive millennial-scale cycle in North Atlantic Holocene and glacial climates, Science, 278, 1257-1266, 1997.

Bond, G., Kromer, B., Beer, J., Muscheler, R., Evans, M. N., Showers, W., Hoffmann, S., Lotti-Bond, R., Hajdas, I., and Bonami, G.: Persistent solar influence on North Atlantic climate during the Holocene, Science, 294, 2130-2136, 2001.

Bordon, A., Peyron, O., Lézine, A.-M., Brewer, S., and Fouache, E.: Pollen-inferred Late-Glacial and Holocene climate in southern Balkans (Lake Maliq), Quatern. Int., 200, 19-30, 2009.

Bout-Roumazeilles, V., Combourieu Nebout, N., Peyron, O., Cortijo, E., and Masson-Delmotte, V.: Connexion between South Mediterranean climate and North African atmospheric circulation during MIS 3 North Atlantic cold events, Quaternary Sci. Rev., 26, 3197-3215, 2007.
Brauer, A., Allen, J. R. M., Mingram, J., Dulski, P., Wulf, S., and Huntley, B.: Evidence for last interglacial chronology and environmental change from Southern Europe, P. Natl. Acad. Sci. USA, 104, 450-455, 2007.

Brewer, S., Guiot, J., and Torre, F.: Mid-Holocene climate change in Europe: a data-model comparison, Clim. Past, 3, 499-512, 2007, http://www.clim-past.net/3/499/2007/.

Cacho, I., Grimalt, J. O., Pelejero, C., Canals, M., Sierro, F. J., Flores, J. A., and Shackleton, N. J.: Dansgaard-Oeschger and Heinrich events imprints in the Alboran Sea paleotemperatures, Paleoceanography, 14, 698-705, 1999

Cacho, I., Grimalt, J. O., Canals, M., Sbaffi, L., Shackleton, N., Schönfeld, J., and Zahn, R.: Variability of the western Mediterranean Sea surface temperature during the last 25000 years and its connection with the northern hemisphere climatic changes, Paleoceanography, 16, 40-52, 2001.

Carrión, J. S., Fuentes, N., González-Sampériz, P., Sánchez Quirante, L., Finlayson, J. C., Fernández, S., and Andrade, A.: Holocene environmental change in a montane region of southern Europe with a long history of human settlement, Quaternary Sci. Rev., 26, 1455-1475, 2007.

Cheddadi, R., Lamb, H. F., Guiot, J., and van der Kaars, S.: Holocene climatic changes in Morocco a quantitative reconstruction from pollen data, Clim. Dynam., 14, 883-890, 1998.

Cheddadi, R., Yu, G., Guiot, J., Harrison, S. P., and Prentice, I. C.: The climate of Europe 6000 years ago, Clim. Dynam., 13, 1-9, 1997.

Cheddadi, R., Fady, B., Françoic, L., Hajar, L., Suc, J.-P., Huang, K., Demarteau, M., Vendramin, G. G., and Ortu, E.: Putative glacial refugia of Cedrus atlantica deduced from Quaternary pollen records and modern genetic diversity, J. Biogeogr., 36(7), 1361-1371, doi:10.1111/j.1365-2699.2008.02063.x, 2009.

Colombaroli, D., Vanniere, B., Chapron, E., Magny, M., and Tinner, W.: Fire-vegetation interactions during the Mesolithic-Neolithic transition at Lago dell'Accesa, Tuscany, Italy, The Holocene, 18, 5, 679-692, 2008.

Comas, M. C., Zahn, R., Klaus, A., et al.: Proc. ODP, Init. Reports., 161: College Station, TX (Ocean Drilling Program), 1023 pp., 1996.

Combourieu Nebout, N., Paterne, M., Turon, J. L., and Siani, G.: A high-resolution record of the last deglaciation in the Central Mediterranean Sea: Palaeovegetation and Palaeohydrological evolution, Quaternary Sci. Rev., 17, 303-317, 1998.

Combourieu Nebout, N., Londeix, L., Baudin, F., Turon, J.-L., von Grafenstein, R., and Zahn, R.: Quaternary marine and continental paleoenvironments in the western Mediterranean (Site 976, Alboran Sea): palynological evidence, in: Proc. ODP Sci. Results, 161: College Station, TX (Ocean Drilling Program), edited by: Zahn, R., Comas, M. C., and Klaus, A., 457-468, 1999.

Combourieu Nebout, N., Turon, J.-L., Zahn, R., Capotondi, L., Londeix, L., and Pahnke, K.: Enhanced aridity and atmospheric high-pressure stability over the western Mediterranean during the North Atlantic cold events of the past 50 k.y., Geology, 30, 863866, 2002.

Davis, B. A. S., Brewer, S., Stevenson, A. C., Guiot, J., and data contributor: The temperature of Europe during the Holocene reconstructed from pollen data, Quaternary Sci. Rev., 22, 17011716, 2003.

Dormoy, I., Peyron, O., Combourieu-Neboutb, N., Goring, S., 
Kotthoff, U., Magny, M., and Pross, J.: Terrestrial climate variability and seasonality changes in the Mediterranean region between 15000 and 4000 years BP deduced from marine pollen records, Clim. Past Discuss., 5, 735-770, 2009,

http://www.clim-past-discuss.net/5/735/2009/.

Drescher-Schneider, R., de Beaulieu, J.-L., Magny, M., WalterSimonet, A.-V., Bossuet, G., Millet, L., Brugiapaglia, E. L., and Drescher, A.: Vegetation history, climate and human impact over the last 15000 years at Lago dell'Accesa (Tuscany, Central Italy), Veg. Hist. Archaeobot., 16(4), 279-299, 2007.

Elliot, M., Labeyrie, L., Bond, G., Cortijo, E., Turon, J. L., Tisnerat, N., and Duplessy, J. C.: Millennial scale iceberg discharges in the Irminger Basin during the last glacial period: Relationship with the Heinrich events and environmental settings, Paleoceanography, 13, 433-446, 1998.

Faegri, K. and Iversen, J.: Textbook of Pollen Analysis, Munksgaard, Copenhagen, Denmark, 237 pp., 1964.

Fletcher, W. J. and Sánchez-Goñi, M. F.: Orbital-sub-orbital-scale climate impact on vegetation of the western Mediterranean basin over the last 48000 yr, Quaternary Res., 70(3), 451-464, 2008.

Fletcher, W. J., Sanchez Goñi, M. F., Peyron, O., and Dormoy, I.: Abrupt climate changes of the last deglaciation detected in a western Mediterranean forest record, Clim. Past Discuss., 5, 203-235, 2009, http://www.clim-past-discuss.net/5/203/2009/.

Frigola, J., Moreno, A., Cacho, I., Canals, M., Sierro, F. J., Flores, J. A., Grimalt, J. O., Hodell, D. A., and Curtis, J. H.: Holocene climate variability in the western Mediterranean region from a deepwater sediment record, Paleoceanography, 22, PA2209, doi:10.1029/2006PA001307, 2007.

Genty, D., Blamart, D., Ghaleb, B., Plagnes, V., Causse, Ch., Bakalowicz, M., Zouari, K., Chkir, N., Hellstrom, J., Wainer, K., and Bourge, F.: Timing and dynamics of the last deglaciation from European and North African $\delta^{13} \mathrm{C}$ stalagmite profilescomparison with Chinese and South Hemisphere stalagmites, Quaternary Sci. Rev., 25, 2118-2142, 2006.

Grafenstein, U., Von Erlenkeusen, H., Brauer, A., Jouzel, J., and Johnsen, S. J.: A mid-European decadal isotope-climate record from 15500 to 5000 years BP, Science, 284, 1654-1657, 1999.

Grieser, J., Giommes, R., and Bernardi, M.: New LocClim - the Local Climate Estimator of FAO, Geophys. Res. Abstr., 8, 08305 , 2006.

Grimm, E. C.: Coniss: a Fortran 77 program for stratigraphically constrained cluster analysis by the method of incremental sum of squares, Comput. Geosci., 13, 13-35, 1986.

Guiot, J.: Methodology of the last climatic cycle reconstruction in France from pollen data, Palaeogeogr. Palaeocl., 80, 49-69, 1990.

Hayes, A., Kucera, M., Kallel, N., Sbaffi, L., and Rohling, E. J.: Glacial Mediterranean sea surface temperatures based on planktonic foraminiferal assemblages, Quaternary Sci. Rev., 24, 9991016, 2005.

Heusser, L. E. and Balsam, W. L.: Pollen distribution in the northeast Pacific Ocean, Quaternary Res., 7, 45-62, 1977.

Hooghiemstra, H., Stalling, H., Agwu, C. O. C., and Dupont, L. M.: Vegetational and climatic changes at the northern fringe of the Sahara 250 000-5000 years BP: evidence from 4 marine pollen records located between Portugal and the Canary Islands, Rev. Palaeobot. Palyno., 74, 1-53, 1992.

Hooghiemstra, H., Leìzine, A.-M., Leroy, S. A. G., Dupont, L., and
Marret, F.: Late Quaternary palynology in marine sediments: a synthesis of the understanding of pollen distribution patterns in the NW African setting, Quatern. Int., 148, 29-44, 2006.

Huntley, B. and Prentice, I. C.: July temperatures in Europe from pollen data, 6000 years before present, Science, 241, 4866, 687690, 1988.

Huntley, B., Watts, W. A., Allen, J. R. M., and Zolitschka, B.: Palaeoclimate, chronology and vegetation history of the Weichselian Lateglacial: comparative analysis of data from three cores at Lago Grande di Monticchio, southern Italy, Quaternary Sci. Rev., 18, 945-960, 1999.

Huntley, B., Alfano, M. J., Allen, J. M. R., Pollard, D., Tzedakis, P. C., de Beaulieu, J.-L., Grüger, E., and Watts, B.: European vegetation during marine stage 3, Quaternary Res., 59, 195-212, 2003.

Hutson, W.: The Agulhas current during the Late Pleistocene: analysis of modern faunal analogs, Science, 207, 64-66, 1980.

IPCC: Climate Change 2007: Synthesis Report, Contribution of Working Groups I, II and III to the Fourth Assessment Report of the Intergovernmental Panel on Climate Change (Core Writing Team, edited by: Pachauri, R. K. and Reisinger, A.), IPCC, Geneva, Switzerland, 758, 104 pp., 2007.

Jalut, G., Amat, A. E., Bonnet, L., Gauquelin, T., and Fontugne, M.: Holocene climatic changes in the western Mediterranean from south-east France to south-east Spain, Palaeogeogr. Palaeocl., 160, 255-290, 2000.

Jalut, G., Dedoubat, J. J., Fontugne, M., and Otto, T.: Holocene circum-Mediterranean vegetation changes: Climate forcing and human impact, Quatern. Int., 200, 4-18, 2009.

Johnsen, S. J., Dahl-Jensen, D., Gundestrup, N., Steffensen, J. P., Clausen, H. B., Miller, H., Masson-Delmotte, V., Sveinbjörnsdottir, A. E., and White, J.: Oxygen isotope and palaeotemperature records from six Greenland ice-core stations: Camp Century, Dye3, GRIP,GISP2, Renland and NorthGRIP, J. Quaternary Sci., 16, 299-307, 2001.

Jost, A., Lunt, D., Kageyama, M., Abe-Ouchi, A., Peyron, O., Valdes, P. J., and Ramstein, G.: High resolution simulations of the Last Glacial Maximum climate over Europe: a solution to discrepanciers with pollen-based paleoclimatic reconstructions?, Clim. Dynam., 24, 577-590, doi:10.1007/s00382-005-0009-4., 2005.

Kageyama, M., Combourieu Nebout, N., Sepulchre, P., Peyron, O., Krinner, G., Ramstein, G., and Cazet, J.-P.: The Last Glacial Maximum and Heinrich Event 1 in terms of climate and vegetation around the Alboran Sea: a preliminary model-data comparison, CR Geosci., 337, 983-992, 2005.

Kallel, N., Paterne, M., Labeyrie, L., Duplessy, J.-C., and Arnold, M.: Temperature and salinity records of the Tyrrhenian Sea during the last 18000 years, Palaeogeogr. Palaeocl., 135, 97-108, 1997.

Kotthoff, U., Pross, J., Müller, U. C., Peyron, O., Schmiedl, G., Schulz, H., and Bordon, A.: Climate dynamics in the borderlands of the Aegean Sea during formation of sapropel S1 deduced from a marine pollen record, Quaternary Sci. Rev., 27(7-8), 832-845, 2008 a.

Kotthoff, U., Müller, U. C., Pross, J., Schmiedl, G., Lawson, I. T., van de Schootbrugge, B., and Schulz, H.: Late Glacial and Holocene vegetation dynamics in the Aegean region: An integrated view based on pollen data from marine and terrestrial 
archives, The Holocene, 18, 1019-1032, 2008b.

Kucera, A., Rosell-Mele, A., Schneider, R., Waelbroeck, C., and Weinelt, M.: Multiproxy approach for the reconstruction of the glacial ocean, surface (MARGO), Quaternary Sci. Rev., 24, 813819, 2005.

Kuhleman, J., Rohling, E. J., Krumrei, I., Kubik, P., Ivy-Ochs, S., and Kucera, M.: Regional synthesis of Mediterranean atmospheric circulation during the last Glacial Maximum, Science, 321, 1338-1340, 2008.

Lamb, H. F., Eicher, U., and Switsur, V. R.: An 18000 -year record of vegetation, lake level and climatic change from Tigalmine, Middle Atlas, Morocco, J. Biogeogr., 16, 65-74, 1989,

Lamb, H. F., Gasse, F., Benkaddour, A., Hamouti, N. E. P., van der Kaars, S., Perkins, W. T., Pearce, N. J., and Roberts, C. N.: Relation between century-scale Holocene arid intervals in tropical and temperate zones, Nature, 373, 134-137, 1995.

Lionello, P., Malanotte-Rizzoli, P., Boscolo, R., Alpert, P., Artale, V., Li, L., Luterbacher, J., May, W., Trigo, R., Tsimplis, M., Ulbric, U., and Xoplaki, E.: The Mediterranean climate: an overview of the main characteristics and issues, in: Mediterranean Climate Variability, Developments in earth and Environmental Sciences, edited by: Lionello, P., Malanotte-Rizzoli, P., and Boscolo, R., Elsevier, Amsterdam, 4, 1-26, 2006.

Lowe, J. J., Rasmussen, S. O., Björck, S., Hoek, W. Z, Steffensen, J. P., Walkere, M. J. C., Yu, Z. C., and the INTIMATE group: Synchronisation of palaeoenvironmental events in the North Atlantic region during the Last Termination: a revised protocol recommended by the INTIMATE group, Quaternary Sci. Rev., 27, 6-17, 2008.

Magny, M., Bégeot, C., Guiot, J., and Peyron, O.: Contrasting patterns of hydrological changes in response to Holocene climate cooling phases, Quaternary Sci. Rev., 22, 1589-1596, 2003.

Magny, M., de Beaulieu, J. L., Drescher-Schneider, R., Vanniere, B., Walter-Simonnet, A. V., Millet, L., Bossueta, G., and Peyron, O.: Climatic oscillations in central Italy during the Last GlacialHolocene transition: the record from Lake Accesa, J. Quaternary Sci., 21, 1-10, 2006.

Magny, M., de Beaulieu, J.-L., Drescher-Schneiderc, R., Vanniere, B., Walter-Simonne, A.-V., Miras, Y., Millet, L., Bossueta, G., Peyron, O., Brugiapaglia, E., and Leroux, A.: Holocene climate changes in the central Mediterranean as recorded by lake-level fluctuations at Lake Accesa (Tuscany, Italy), Quaternary Sci. Rev., 26, 1736-1756, 2007.

Magny, M., Peyron, O., Gauthier, E., Rouèche, H., Bordon, A., Billaud, Y., Chapron, E., Marguet, A., Pétrequin, P., and Vannière, B.: Quantitative reconstruction of climatic variations during the Bronze and early Iron ages based on pollen and lake-level data in the NW Alps, France, Quatern. Int., 200, 102-110, 2009.

Magri, D. and Parra, I.: Late Quaternary western Mediterranean pollen records and African winds, Earth Planet. Sc. Lett., 200, 401-408, 2002.

Marchal, O., Cacho, I., Stocker, T. F., Grimalt, J. O., Calvo, E., Martrat, B., Shackleton, N., Vautravers, M., Cortijo, E., van Kreveld, S., Andersson, C., Koç, N., Chapman, M., Sbaffi, L., Duplessy, J.-C., Sarnthein, M., Turon, J.-L., Duprat, J., and Jansen, E.: Apparent long-term cooling of the sea surface in the northeast Atlantic and Mediterranean during the Holocene, Quaternary Sci. Rev., 21, 455-483, 2002.

Mix, A., Bard, E., and Schneider, R.: Environmental processes of the ice age: land, oceans, glaciers (EPILOG), Quaternary Sci. Rev., 20, 627-657, 2001.

Müller, S., Tarasov, P. E., Andreev, A. A., and Diekmann, B.: Late Glacial to Holocene environments in the present-day coldest region of the Northern Hemisphere inferred from a pollen record of Lake Billyakh, Verkhoyansk Mts, NE Siberia, Clim. Past, 5, 73-84, 2009, http://www.clim-past.net/5/73/2009/.

Naughton, F., Sánchez Goni, M. F., Desprat, S., Turon, J. L., Duprat, J., Malaizé, B., Joli, C., Cortijo, E., Drago, T., and Freitas, M. C.: Present-day and past (last 25000 years) marine pollen signal off western Iberia, Mar. Micropaleontol., 62, 91114, 2007.

New, M., Hulme, M., and Jones, P. D.: Representing twentieth century space-time climate variability. Part 2: development of 190196 monthly grids of terrestrial surface climate, J. Climate, 13, 2217-2238, 2000.

North Greenland Ice Core Project members: High-resolution record of northern hemisphere climate extending into the last interglacial period, Nature, 431, 147-151, 2004.

Overpeck, J. T., Webb, T., and Prentice, I. C.: Quantitative interpretation of fossil pollen spectra: Dissimilarity coefficients and the method of modern analogs, Quaternary Res., 23, 87-108, 1985.

Ozenda, P.: Sur les étages de végétation dans les montagnes du bassin méditerranéen, Documents de Cartographie Ecologique, 16, 1-32, 1975.

Peñalba, M. C., Arnold, M., Guiot, J., Duplessy, J.-C., and de Beaulieu, J.-L.: Termination of the Last Glaciation in the Iberian Peninsula inferred from the pollen sequence of Quintanar de la Sierra, Quaternary Res., 48, 205-214, 1997.

Pérez-Folgado, M., Sierro, F. J., Flores, J. A., Cacho, I., Grimalt, J. O., Zahn, R., and Shackleton, N.: Western Mediterranean planktonic foraminifera events and millennial climatic variability during the last $70 \mathrm{kyr}$, Mar. Micropaleontol., 48, 49-70, 2004.

Peyron, O., Guiot, J., Cheddadi, R., Tarasov, P., Reille, M., de Beaulieu, J.-L., Bottema, S., and Andrieu, V.: Climatic reconstruction in Europe for $18000 \mathrm{yr}$ BP from pollen data, Quaternary Res., 49, 183-196, 1998.

Peyron, O., Bégeot, C., Brewer, S., Heiri, O., Magny, M., Millet, L., Ruffaldi, E. P., Van Campo, E., and Yu, G.: Late glacial climatic changes in eastern France (Lake Lautrey) from pollen, lakelevels, and chironomids, Quaternary Res., 64, 197-211, 2005.

Pons, A. and Reille, M.: The Holocene and Upper Pleistocene pollen record from Padul (Granada, Spain): a new study, Palaeogeogr. Palaeocl., 66, 243-263, 1988.

Polunin, O. and Walters, M.: A Guide to the Vegetation of Britain and Europe, Oxford University Press, New York, USA, 238 pp., 1985.

Prentice, I. C, Guiot, J., and Harrison, S. P.: Mediterranean vegetation, lake levels and palaeoclimate at the Last Glacial Maximum, Nature, 360, 658-660, doi:10.1038/360658a0, 1992.

Prentice, C., Guiot, J., Huntley, B., Jolly, D., and Cheddadi, R.: Reconstructing biomes from palaeoecological data: a general method and its application to European pollen data at 0 and $6 \mathrm{ka}$, Clim. Dynam., 12(3), 185-194, 1996.

Quézel, P.: Réflexions sur l'évolution de la flore et de la végétation au Maghreb méditerranéen, Ibis Press, Paris, France, 117 pp., 2002.

Quézel, P. and Médail, F.: Ecologie et biogéographie des forêts du bassin méditerranéen, Elsevier-Lavoisier eds, Paris, France, 571 
pp., 2003.

Ramstein, G., Kageyama, M., Guiot, J., Wu, H., Hély, C., Krinner, G., and Brewer, S.: How cold was Europe at the Last Glacial Maximum? A synthesis of the progress achieved since the first PMIP model-data comparison, Clim. Past, 3, 331-339, 2007, http://www.clim-past.net/3/331/2007/.

Rasmussen, S. O., Andersen, K. K., Svensson, A. M., Steffensen, J. P., Vinther, B. M., Clausen, H. B., Siggaard-Andersen, M.L, Johnsen, S. J., Larsen, L. B., Dahl-Jensen, D., Bigler, M., Rothlisberger, R., Fischer, H., Goto-Azuma, K., Hansson, M. E., and Ruth, U.: A new Greenland ice core chronology for the last glacial termination, J. Geophys. Res., 111, D06102, doi:10.1029/2005JD006079, 2006.

Rasmussen, S. O., Vinther, B. M., Clausen, H. B., and Andersen, K. K.: Early Holocene climate oscillations recorded in three Greenland ice cores, Quaternary Sci. Rev., 26, 1907-1914, 2007.

Rivas-Martinez, S.: Etages bioclimatiques, secteurs chronologiques et séries de végétation de l'Espagne méditerranéenne, Ecol. Medit., 8, 275-288, 1982.

Rohling, E. J., Hayes, A., De Rijk, S., Kroon, D., Zachariasse, W. J., and Eisma, D.: Abrupt cold spells in the northwest Mediterranean, Paleoceanography, 13(4), 316-322, 1998.

Rohling, E. J., Mayewski, P. A., Abu-Zied, R. H., Casford, J. S. L., and Hayes, A.: Holocene atmosphere-ocean interactions: records from Greenland and the Aegean Sea, Clim. Dynam., 18, 587-593, doi:10.1007/s00382-001-0194-8, 2002.

Sadori, L. and Narcisi, B.: The post glacial record of environmental history from Lago di Pergusa, Sicily, the Holocene, 11(6), 655371, 2001.

Sánchez Goñi, M. F., Cacho, I., Turon, J.-L., Guiot, J., Sierro, F. J., Peypouquet, J.-P., Grimalt, J. O., and Shackleton, N. J.: Synchroneity between marine and terrestrial responses to millennial scale climatic variability during the last glacial period in the Mediterranean region, Clim. Dynam., 19, 95-105, 2002.

Siani, G., Paterne, M., Arnold, M., Bard, E., Metivier, B., Tisnerat, N., and Bassinot, F.: Radiocarbon reservoir ages in the Mediterranean Sea and Black Sea, Radiocarbon, 42, 271-280, 2000.

Siani, G., Paterne, M., Michel, E., Sulpizio, R., Sbrana, A., Arnold, M., and Haddad, G.: Mediterranean Sea surface radiocarbon reservoir age changes since the Last Glacial Maximum, Science, 294, 1917-1920, 2001.

Stuiver, M. and Reimer, P. J.: Extended ${ }^{14} \mathrm{C}$ database and revised CALIB radiocarbon calibration program, Radiocarbon, 35, 215230, 1993.

Stuiver, M., Reimer, P. J., Bard, E., Beck, W., Burr, G. S., Hughen, K. A., Kromer, B., McCormac, F. G., van der Plicht, J., and Spurk, M.: INTCAL98 radiocarbon age calibration, 24000 cal BP, Radiocarbon, 40, 1041-1083, 1998.
Tarasov, P. E., Guiot, J., Cheddadi, R., Andreev, A. A., Bezusko, L., Blyakharchuk, T. A., Dorofeyuk, N. I., Filimonova, L. V., Volkova, V. S., and Zernitchkaya, V. P.: Climate in northern Eurasia 6000 years ago reconstructed from pollen data, Earth Planet. Sc. Lett., 171, 635-645, 1999a.

Tarasov, P. E., Peyron, O., Guiot, J., Brewer, S., Volkova, V. S., Bezusko, L., Dorofeyuk, N. I., Kvavadze, E. V., Osipova, I. M., and Panova, N. K.: Last glacial Maximum climate of the former Soviet Union and Mongolia reconstructed from pollen and plant macrofossil data, Clim. Dynam., 15, 227-240, 1999 b.

Tinner, W., van Leeuwen, J. F. N., Colombaroli, D., Vescovi, E., van der Knaap, W. O. Henne, P. D., Pasta, S., D’ Angelo, S., and La Mantia, T.: Holocene environmental and climatic changes at Gorgo Basso, a coastal lake in southern Sicily, Italy, Quaternary Sci. Rev., 28, 1498-1510, 2009.

Turon, J.-L.: Le palynoplancton dans l'environnement actuel de l'Atlantique Nord-oriental. Evolution climatique et hydrologique depuis le dernier maximum glaciaire, Ph.D. thesis, Bordeaux 1 University, France, 1984.

Turon, J.-L., Lézine, A. M., and Denèfle, M.: Land-sea correlations for the last glaciation inferred from a pollen and dinocyst record from the Portuguese margin, Quaternary Res., 59, 88-96, 2003.

Tzedakis, P. C.: Seven ambiguities in the Mediterranean palaeoenvironmental narrative, Quaternary Sci. Rev., 26, 2042-2066, 2007.

Walter, W., Harnickell, E., and Mueller-Dombois, D.: Climate Diagram Maps, Springer-Verlag, 1975.

Watts, W. A., Allen, J. R. M., Huntley, B., and Fritz, S. C.: Vegetation history and climate of the last 15000 years at Laghi di Monticchio, Southern Italy, Quaternary Sci. Rev., 15, 113-132, 1996.

Wiersma, A. P. and Renssen, H.: Model-data comparison for the $8.2 \mathrm{ka}$ BP event: confirmation of a forcing mechanism by catastrophic drainage of Laurentide Lakes, Quaternary Sci. Rev., 25, 63-88, 2006.

Woodward, F. I.: Climate and plant distribution, Cambridge Univ. Press, Cambridge, England, 1987.

Wohlfarth, B.: The chronology of the last termination: A review of radiocarbon-dated, high-resolution terrestrial stratigraphies, Quaternary Sci. Rev., 15(4), 267-284, 1996.

Wu, H., Guiot, J., Brewer, S., and Guo, Z.: Climatic changes in Eurasia and Africa at the last glacial maximum and mid-Holocene: reconstruction from pollen data using inverse vegetation modelling, Clim. Dynam., 29, 211-229, doi:10.1007/s00382-007-0231-3, 2007. 